\title{
ARTICLES
}

\section{APPLYING THE EUROPEAN CONVENTION ON HUMAN RIGHTS TO THE CONFLICT IN UKRAINE}

\author{
STUART WALLACE, \\ University of Cambridge (Cambridge, United Kingdom) \\ CONALL MALLORY, \\ Newcastle University (Newcastle upon Tyne, United Kingdom)
}

DOI: 10.17589/2309-8678-2018-6-3-8-78

The "annexation" of Crimea by the Russian Federation and the ongoing conflict in Eastern Ukraine have resulted in widespread human rights abuses. Both Ukraine and the Russian Federation are signatories to the European Convention on Human Rights and the Convention should apply within the territory and to the conflict. However, recent applications to the European Court of Human Rights reveal a great deal of confusion over which State bears responsibility for protecting human rights in different parts of Ukraine. This article seeks to shine a light on this problem presenting a deep analysis of the European Court of Human Rights'jurisprudence and discussing how it applies to both the conflict in Eastern Ukraine and "annexed" Crimea. It addresses salient issues such as responsibility for the actions of non-state actors and armed groups in Eastern Ukraine and whether the legality of the "annexation" has any bearing on the human rights obligations of each State. The article presents a detailed critique of recent judgments from the European Court of Human Rights arguing that the jurisprudence of the Court has created a bewildering degree of complexity and uncertainty as to the obligations of each State and discussing the practical implications of this uncertainty.

Keywords: Ukraine; Russia; armed conflict; European Convention on Human Rights; Crimea; jurisdiction; state responsibility; territory; control; belligerent occupation.

Recommended citation: Stuart Wallace \& Conall Mallory, Applying the European Convention on Human Rights to the Conflict in Ukraine, 6(3) Russian Law Journal 8-78 (2018). 


\section{Table of Contents}

\section{Introduction}

\section{Jurisdiction Under the ECHR}

2. The Crimean "Annexation"

\subsection{Scenario 1 - Crimea Has Been Annexed}

2.1.1. Russia's Responsibility for Human Rights

2.1.2. Ukraine's Responsibility for Human Rights

\subsection{Scenario 2 - Crimea is "Occupied" by Russia}

2.2.1. Russia's Responsibility for Human Rights

2.2.2. Is Upholding All Convention Rights in Crimea Feasible?

2.2.3. Ukraine's Responsibility for Human Rights

2.2.4. Loss of Territorial Control with No Impact on Human Rights Obligations

2.2.5. Positive Obligations

\subsection{Conclusion on Crimea}

3. Ukraine's Responsibility for Human Rights

3.1. Scenario 1 - Ukraine Exercises Jurisdiction Throughout Its Territory

3.2. Scenario 2 - Ukraine Owes Only Positive Obligations in Eastern Ukraine

4. Russia's Responsibility for Human Rights

\subsection{Scenario 1 - Russia Exercises Spatial Jurisdiction over Eastern Ukraine}

4.2. Scenario 2 - Russia Exercises Personal Jurisdiction over Individuals

\section{Within Eastern Ukraine}

4.2.1. Pro-Russian Rebels Exercise Direct Control over Individuals

Through Custody

4.2.2. Pro-Russian Rebels Exercise Control over Individuals

Due to Their Location

4.2.3. Pro-Russian Rebels Exercise Control Through Instantaneous Acts

\subsection{Conclusions as to Eastern Ukraine Conclusion}

\section{Introduction}

In November 2013, protests broke out in the Ukraine when the president, Viktor Yanukovych, refused to sign an association agreement with the European Union. 'This was a defining moment in the country's history as it exacerbated longstanding tensions between citizens favouring closer ties with Europe and others who

Ukraine Protests After Yanukovych EU Deal Rejection, BBC News, 30 November 2013 (Aug. 2, 2018), available at http://www.bbc.co.uk/news/world-europe-25162563. 
favoured a closer relationship with Russia. ${ }^{2}$ The protests against Yanukovych gathered in intensity and turned increasingly violent. Yanukovych eventually fled office in February 2014. His government was replaced by an interim administration and the security situation, particularly in the east of the country, continued to worsen. ${ }^{3}$ In late February 2014 pro-Russian groups began to take control of public buildings on the Crimean peninsula and the by the end of spring parts of the Donetsk and Luhansk Oblasts were under the control of similar pro-Russian units. ${ }^{4}$ In May 2015 Ukrainian authorities filed derogations with respect to its human rights obligations under both the European Convention on Human Rights 1950 (hereinafter ECHR) and International Convention on Civil and Political Rights $1966 .{ }^{5}$

In the five years since the conflict began there has been a significant deterioration in the protection of human rights within Ukraine. The Office of the United Nations High Commissioner for Human Rights has stated that the death toll from the conflict now exceeds 2,700, with a further 9,000 individuals injured. ${ }^{6}$ An estimated 1.6 million people have been displaced by the violence. 'Human Rights Watch has reported further human rights abuses, including a high number of enforced disappearances, the intimidation of pro-Ukrainian activists and widespread persecution of minority groups, such as the Tatars. ${ }^{8}$ The UN has further reported on instances of alleged

2 For some historical context on the origins of the conflict in Ukraine see Julia Koch, The Efficacy and Impact of Interim Measures: Ukraine's Inter-State Application Against Russia, 39(1) Boston College International and Comparative Law Review 163, 165-170 (2016).

3 Shaun Walker, Ukraine's Former PM Rallies Protesters After Yanukovych Flees Kiev, The Guardian, 23 February 2014 (Aug. 2, 2018), available at http://www.theguardian.com/world/2014/feb/22/ukrainepresident-yanukovych-flees-kiev.

4 Ukraine Crisis: Timeline, BBC News, 13 November 2014 (Aug. 2, 2018), available at https://www.bbc. co.uk/news/world-middle-east-26248275.

5 Ukrainian Government, Resolution of the Verkhovna Rada of Ukraine on Declaration on Derogation from Certain Obligations Under the International Covenant on Civil and Political Rights and the Convention for the Protection of Human Rights and Fundamental Freedoms, 21 May 2015 (Aug. 2, 2018), available at https://rm.coe.int/CoERMPublicCommonSearchServices/DisplayDCTMContent?d ocumentld=0900001680304c47\#search=ukraine\%20derogate.

6 United Nations Office for the Coordination of Humanitarian Affairs, Ukraine Humanitarian Bulletin, Issue 25, 1 March - 30 April 2018 (Aug. 2, 2018), available at https://reliefweb.int/sites/reliefweb.int/ files/resources/ukraine_-_humanitarian_bulletin_issue_25_-_mar-apr_2018.pdf. See also UN Calls for "New Political Energy" to End the Conflict in Eastern Ukraine, UN News, 29 May 2018 (Aug. 2, 2018), available at https://news.un.org/en/story/2018/05/1010911. The Council on Foreign Relations places the death-toll significantly higher at over 10,000 - Council on Foreign Relations, Global Conflict Tracker, 19 June 2018 (Aug. 2, 2018), available at https://www.cfr.org/interactives/global-conflict-tracker\#!/ conflict/conflict-in-ukraine.

7 UN Calls for "New Political Energy," supra note 6.

8 Crimea: Disappeared Man Found Killed, Human Rights Watch, 18 March 2014 (Aug. 2, 2018), available at https://www.hrw.org/news/2014/03/18/crimea-disappeared-man-found-killed; Crimea: Enforced Disappearances, Human Rights Watch, 7 October 2014 (Aug. 2, 2018), available at https://www.hrw. org/news/2014/10/07/crimea-enforced-disappearances. 
torture, ${ }^{9}$ sexual violence, ${ }^{10}$ threats to commit ethnic cleansing ${ }^{11}$ and forced conscription. $^{12}$

The on-going unrest has created considerable uncertainty as to who is ultimately responsible for guaranteeing human rights protection within the different parts of Ukraine. The violence has clearly reached the threshold of an armed conflict at different times, although the exact categorisation of the hostilities under international law in different parts of the country is open to debate. ${ }^{13}$ There remain ongoing arguments in the international legal forum over whether human rights law applies to armed conflicts or whether it should be superseded by international humanitarian law (hereinafter $\mathrm{IHL}) .^{14}$ Indeed Russia has already argued that human rights law should not be applied to its armed conflict with Georgia in 2008 in an inter-state case before the European Court of Human Rights (hereinafter ECtHR). ${ }^{15}$ Given the similarities between that situation and the Ukraine crisis, it seems likely that Russia will raise a similar argument in cases related to the Ukrainian conflict. While there is some continued merit to these

9 Office of the United Nations High Commissioner for Human Rights, Report on the Human Rights Situation in Ukraine - 16 February to 15 May 2016, 3 June 2016, at 15 (Aug. 2, 2018), available at https:// www.ohchr.org/Documents/Countries/UA/Ukraine_14th_HRMMU_Report.pdf.

10 Office of the United Nations High Commissioner for Human Rights, Conflict-Related Sexual Violence in Ukraine - 14 March 2014 to 31 January 2017, 16 February 2017 (Aug. 2, 2018), available at https:// www.ohchr.org/Documents/Countries/UA/ReportCRSV_EN.pdf.

11 Andrew Korybko, Ethnic and Cultural Cleansing in Ukraine, Global Research, 18 June 2014 (Aug. 2, 2018), available at http://www.globalresearch.ca/ethnic-and-cultural-cleansing-inukraine/5387539.

12 Office of the United Nations High Commissioner for Human Rights, Report on the Human Rights Situation in Ukraine - 16 November 2017 to 15 February 2018, 19 March 2018, at 13 (Aug. 2, 2018), available at https://www.ohchr.org/Documents/Countries/UA/ReportUkraineNov2017-Feb2018_EN.pdf.

13 On the application of the Law of Armed Conflict to Ukraine see Reeves and Wallace who contend that the situation in the Crimea would amount to an international armed conflict, while - due to the challenges in ascertaining Russian influence - the unrest in Eastern Ukraine would only amount to a non-international armed conflict at present. Shane R. Reeves \& David Wallace, The Combatant Status of the "Little Green Men" and Other Participants in the Ukraine Conflict, 91 International Law Student Series US Naval War Collection 361, 382 (2015).

14 Barbara Miltner, Revisiting Extraterritoriality After Al-Skeini: The ECHR and Its Lessons, 33(4) Michigan Journal of International Law 693, 748 (2012); Michelle A. Hansen, Preventing the Emasculation of Warfare: Halting the Expansion of Human Rights Law into Armed Conflict, 194 Military Law Review 1, 65 (2007); Natasha Balendra, Defining Armed Conflict, 29(6) Cardozo Law Review 2461, 2516 (2008); Michael J. Dennis, Application of Human Rights Treaties Extraterritorially to Detention of Combatants and Security Internees: Fuzzy Thinking All Around, 12(2) ILSA Journal of International \& Comparative Law 459, 480 (2006); Heike Krieger, A Conflict of Norms the Relationship Between Humanitarian Law and Human Rights Law in the ICRC Customary Law Study, 11(2) Journal of Conflict \& Security Law 265, 291 (2006); W. Hays Parks, Part IX of the ICRC Direct Participation in Hostilities Study: No Mandate, No Expertise, and Legally Incorrect, 42 New York University Journal of International Law and Politics 769, 830 (2010); Rick Lawson, Really Out of Sight? Issues of Jurisdiction and Control in Situations of Armed Conflict under the ECHR in Margins of Conflict: The ECHR and Transitions to and from Armed Conflict 57 (A. Buyse (ed.), Antwerp: Intersentia, 2011). For discussion on this subject specifically at the ECtHR see Hassan v. United Kingdom, Application No. 29750/09, Judgment (Grand Chamber), 16 September 2014, paras. 96-107.

15 Georgia v. Russia (II), Application No. 38263/08, Decision (Section V), 13 December 2011. 
discussions, the reality is that international human rights law is currently being applied to a variety of military operations including international armed conflicts, ${ }^{16}$ particularly by the ECtHR. The past decades have seen the ECtHR apply the ECHR to a variety of military operations, including international armed conflicts, ${ }^{17}$ foreign belligerent occupations ${ }_{1}^{18}$ peace-support operations ${ }^{19}$ domestic counter-insurgency operations, ${ }^{20}$ and non-international armed conflicts. ${ }^{21}$ This has prompted calls for a shift in focus toward considering the practicalities of how IHRL can actually be applied in day-today military operations at home and abroad. ${ }^{22}$ In the words of one academic, it is time to "stop debating the theory and start defining the pragmatic." ${ }^{\text {"23 }}$ This article therefore works from the assumption that the ECHR applies to the conflict(s) in Ukraine.

At it's the core, the issue of responsibility for human rights protection in Ukraine is a question of jurisdiction and State responsibility, refracted through the unique lens of the European Convention on Human Rights. Section 1 of the Article therefore introduces the issues of jurisdiction and State responsibility arising under the ECHR. The ECtHR has placed de facto control over territory or persons at the centre of its assessments of jurisdiction. However, it is argued throughout this article that the ECtHR has failed to apply its tests for de facto control consistently. This has led to considerable uncertainty over the scope and content of the obligations owed by different States. The following section begins to analyse this issue in the context of Crimea, asking to what extent does Russia, which claims to have annexed Crimea, have responsibility for human rights obligations within that territory? Would the

16 The ICJ has ruled on a number of occasions that international human rights law applies to armed conflict - Armed Activities on the Territory of the Congo (Democratic Republic of the Congo v. Uganda), 2005 I.C.J. 116, 231. See also Legal Consequences of the Construction of a Wall in Occupied Palestinian Territory, Advisory Opinion, 2004 I.C.J. 136, 178.

17 Cyprus v. Turkey, Applications No. 6780/74 and 6950/75, Decision, 26 May 1975; Georgia v. Russia (II), supra note 15.

18 The occupation of Iraq in Al-Skeini and Others v. United Kingdom, Application No. 55721/07, Judgment (Grand Chamber), 7 July 2011.

19 Kosovo in Behrami v. France, Application No. 71412/01, Decision (Grand Chamber), 31 May 2007.

20 Counter-insurgency in South-East Turkey in Ergi v. Turkey, Case No. 66/1997/850/1057, Judgment, 28 July 1998.

21 Russian operations in Chechnya in Isayeva v. Russia, Application No. 57950/00, Decision (Section I), 24 February 2005.

22 Naz K. Modirzadeh, The Dark Sides of Convergence: A Pro-Civilian Critique of the Extraterritorial Application of Human Rights Law in Armed Conflict, 86 International Law Student Series US Naval War Collection 349, 368 (2010); lain Scobbie, Principle of Pragmatics - The Relationship Between Human Rights Law and the Law of Armed Conflict, 14(3) Journal of Conflict and Security Law 449, 458 (2009); Daniel Bethlehem, The Relationship Between International Humanitarian Law and International Human Rights Law in Situations of Armed Conflict, 2(2) Cambridge Journal of International and Comparative Law 180, 195 (2013).

23 Geoffrey Corn, Mixing Apples and Hand Grenades The Logical Limits of Applying Human Rights Norms to Armed Conflict, 1(1) Journal of International Humanitarian Legal Studies 52, 90 (2010). 
answer to this question be different if annexation has not occurred and the invading state is instead in belligerent occupation of that territory? The third part of the article examines the situation in Eastern Ukraine. It applies the ECtHR's jurisprudence to various facets of the conflict asking to what extent is Ukraine's jurisdiction displaced by the ongoing conflict? To what extent could Russia be held responsible for the activities of armed groups in Eastern Ukraine?

\section{Jurisdiction Under the ECHR}

According to Article 1, a State's obligations under the ECHR only extend to individuals "within their jurisdiction.".24 The State's jurisdiction is therefore a threshold criterion, which must be met before the treaty obligations begin to apply. ${ }^{25}$ The term jurisdiction can describe many different things. It can, for example, refer to geographical boundaries or to the limits of a court's authority. ${ }^{26}$ When one refers to a State's jurisdiction under general international law, one is referring to a manifestation of its sovereignty. A State manifests its sovereignty over territory by exercising legislative, judicial and executive jurisdiction over it, ${ }_{1}^{27}$ although this is different from the type of jurisdiction contemplated in Article 1 ECHR. Many of the terms used here, sovereignty, jurisdiction, authority are synonymous with control and control is the key factor. Territory can be viewed as the medium, the spatial realm, in which the State exercises its control. Thus, when the ECtHR speaks of jurisdiction under Article 1 being primarily territorial, as it often does, ${ }_{1}^{28}$ it should be understood

24 Convention for the Protection of Human Rights and Fundamental Freedoms, 4 November 1950, E.T.S. 5, Art. 1. Michael O'Boyle, The European Convention on Human Rights and Extraterritorial Jurisdiction: A Comment on "Life After Bankovic" in Extraterritorial Application of Human Rights Treaties 125 (F. Coomans \& M.T. Kamminga (eds.), Antwerp: Intersentia, 2004); Marko Milanovic \& Tatjana Papic, As Bad as It Gets: The European Court of Human Rights's "Behrami and Saramati" Decision and General International Law, 58(2) International \& Comparative Law Quarterly 267, 272 (2009); Ralph Wilde, Legal "Black Hole"? Extraterritorial State Action and International Treaty Law on Civil and Political Rights, 26(3) Michigan Journal of International Law 739, 797-798 (2005).

Ilascu and Others v. Moldova and Russia, Application No. 48787/99, Judgment (Grand Chamber), 8 July 2004, para. 312; Marko Milanovic, From Compromise to Principle: Clarifying the Concept of State Jurisdiction in Human Rights Treaties, 8 Human Rights Law Review 411, 415 (2008).

26 Peter Malanczuk, Akehurst's Modern Introduction to International Law 109 ( $7^{\text {th }}$ ed., New York: Routledge, 1997).

27 Lassa Oppenheim et al., Oppenheim's International Law. Vol. 1: Peace. Parts 2-4 458 (Harlow: Longman, 1992); Ian Brownlie, Principles of Public International Law 299 (Oxford: Oxford University Press, 2008); Antonio Cassese, International Law 50 (Oxford: Oxford University Press, 2005); For a full explanation of what each type of jurisdiction entails see Malcolm Shaw, International Law 649-651 (Cambridge: Cambridge University Press, 2008).

28 See, for example, Banković and Others v. Belgium and Others, Application No. 52207/99, Decision (Grand Chamber), 12 December 2001, para. 61; Hirsi Jamaa v. Italy, Application No. 27765/09, Judgment (Grand Chamber), 23 February 2012, para. 71; llaşcu and Others v. Moldova and Russia, supra note 25, para. 312; Al-Skeini and Others v. United Kingdom, supra note 18, para. 131. 
that possession of territory is a natural condition of Statehood and territory is the spatial realm in which the State's jurisdiction/control is principally manifested.

Using de facto control as an indicator of the exercise of jurisdiction has been a consistent characteristic of the European Court, and its forebear the European Commission on Human Rights, for decades. Conceptualising jurisdiction in this manner is both consistent with the practice of other international human rights bodies and is potentially the most human rights-friendly approach available to the ECtHR. For instance, the UN Convention Against Torture has been interpreted to apply to "all areas where the state party exercises, directly or indirectly, in whole or in part, de jure or de facto effective control."29 Similarly, obligations arising from the ICCPR have been interpreted to extend to all individuals "within the power or effective control" of a state..$^{30}$ In theory at least, such an approach recognises individuals within the Convention's protection at times when they are most vulnerable to the power of the State, as that State, through its agents, is exercising control over either them or the territory in which they are located.

Loizidou v. Turkey ${ }^{31}$ is an example of the ECtHR's approach to de facto control over territory. In this landmark case, the applicant owned property in Northern Cyprus and was prevented from accessing it following the Turkish invasion of Cyprus and the de facto partition of the island. She alleged that Turkey was responsible for denying her peaceful enjoyment of her property. The ECtHR had to decide whether territory in Northern Cyprus, which was occupied by Turkey since the 1970s, came within the jurisdiction of Turkey for the purposes of Article 1. When deciding the issue of jurisdiction, the ECtHR outlined its approach to what has been widely referred to as spatial jurisdiction. ${ }^{32}$ It stated that

the responsibility of a Contracting Party may also arise when as a consequence of military action - whether lawful or unlawful - it exercises effective control of an area outside its national territory. The obligation to secure, in such an area, the rights and freedoms set out in the Convention, derives from

29 UN Committee Against Torture (CAT), General Comment No. 2: Implementation of Article 2 by States Parties, 24 January 2008, CAT/C/GC/2, para. 16.

30 UN Human Rights Committee (HRC), General Comment No. 31 [80], The Nature of the General Legal Obligation Imposed on States Parties to the Covenant, 26 May 2004, CCPR/C/21/Rev.1/Add.13, para. 10.

31 Loizidou v. Turkey (Preliminary Objections), Application No. 15318/89, Judgment (Grand Chamber), 23 March 1995.

32 See, for example, Marko Milanovic, Al-Skeini and Al-Jedda in Strasbourg, 23(1) European Journal of International Law 121, 122 (2012); Ralph Wilde, The Extraterritorial Application of International Human Rights Law on Civil and Political Rights in Routledge Handbook of International Human Rights Law 635, 641 (S. Sheeran \& N. Rodley (eds.), Abingdon, UK: Routledge, 2013); Lea Raible, The Extraterritoriality of the ECHR: Why Jaloud and Pisari Should Be Read as Game Changers, 2 European Human Rights Law Review 161, 163 (2016). 
the fact of such control whether it be exercised directly, through its armed forces, or through a subordinate local administration. ${ }^{33}$

There are several noteworthy elements in this statement. Firstly, the ECtHR refers to effective control of "an area" e.g. piece of territory as opposed to individual people. Secondly, the ECtHR does not specify that the State's obligation is only to secure certain rights, it refers to the rights and freedoms in general, implying that the State must guarantee all of the rights and freedoms in the Convention. ${ }^{34}$ The ECtHR later confirms this in the case of Cyprus v. Turkey when it states

Having effective overall control over Northern Cyprus [...] Turkey's "jurisdiction" must be considered to extend to securing the entire range of substantive rights set out in the Convention and those additional Protocols which she has ratified. ${ }^{35}$

Interestingly the ECtHR makes no direct mention of the procedural obligations here. However, it has since applied the procedural obligations in Article 2, which demand investigation of suspicious deaths, extra-territorially in the cases of Jaloud v. Netherland ${ }^{36}$ and Al-Skeini v. UK, ${ }_{1}^{37}$ so one can assume that they must also be guaranteed. These cases are discussed in detail below. Finally, and perhaps most importantly, the ECtHR refers to the obligation to secure the rights deriving from the fact that Turkey is exercising control over the territory. Thus, the factual control that Turkey exercised over territory was crucial in determining that jurisdiction arose.

A similar emphasis on de facto control is evident with the so-called "personal jurisdiction" approach. ${ }^{38}$ In one of the earliest forays into the application of human rights during extra-territorial armed conflicts, also involving the situation in Northern Cyprus, the European Commission on Human Rights stated that "authorised agents of Turkey [...] bring any other persons or property in Cyprus 'within the jurisdiction' of Turkey, in the sense of Article 1 of the Convention, to the extent that they exercise control over such persons or property."39 This de facto control approach has been

33 Loizidou v. Turkey (Preliminary Objections), supra note 31, para. 62.

34 Noam Lubell, Human Rights Obligations in Military Occupation, 94(885) International Review of the Red Cross 317, 320 (2012).

Cyprus v. Turkey, Application No. 25781/94, Judgment, 10 May 2001, para. 77.

36 Jaloud v. Netherlands, Application No. 47708/08, Judgment (Grand Chamber), 20 November 2014.

37 Al-Skeini and Others v. United Kingdom, supra note 18.

38 See, for example, Cedric Ryngaert, Clarifying the Extraterritorial Application of the European Convention on Human Rights, 28(74) Utrecht Journal of International and European Law 57, 59 (2012); Marko Milanovic, Extraterritorial Application of Human Rights Treaties: Law, Principles, and Policy 173 (Oxford: Oxford University Press, 2011). 
applied subsequently in numerous decisions, largely relating to instances when an individual is brought within the custody of a Contracting Party to the Convention. ${ }^{40}$ Thus, the ECtHR contends that de facto control is the decisive factor in determining the existence of both of these types of jurisdiction under the ECHR. ${ }^{41}$

As will be demonstrated in our analysis of the situation in Ukraine below, the problem lies not with the conception of jurisdiction in terms of de facto control, but rather with the chronically indecisive and inconsistent approach the ECtHR has taken to interpreting and applying de facto control in cases involving violations of the Convention in both domestic and foreign armed conflicts.

\section{The Crimean "Annexation"}

Shortly after Viktor Yanukovych fled Ukraine in February 2014, pro-Russian gunmen took control of key government buildings in Crimea. ${ }^{42}$ Over the following weeks, Russian forces based in Sevastopol, supported by troops from the Russian mainland, took control of the entire Crimean Peninsula. A referendum was then held on 16 March on whether Crimea should become part of Russia, which was passed. ${ }^{43}$ The territory was formally annexed by Russia through the Treaty on Accession of the Republic of Crimea to Russia, ${ }^{44}$ which was followed by a domestic legal act of the Russian State. The "annexation" of the Crimean Peninsula gives rise to a very important question - who is now responsible for protecting human rights in this territory, Ukraine, Russia or do they each have obligations to uphold?

Before discussing this further, it is important to clear up the difference between belligerent occupation and annexation, which is of crucial importance. Under IHL, territory is considered occupied when it is placed under the authority of the hostile army and the occupation extends only to the territory where its authority has been established and can be exercised.$^{45}$ Belligerent occupation is considered a transient

40 See, for example, Öcalan v. Turkey (Merits), Application No. 46221/99, Judgment (Grand Chamber), 12 May 2005, para. 91; Freda v. Italy, Application No. 8916/80, Decision, 7 October 1980.

41 As opposed to the exercise of legal authority. See on this Mirja Trilsch \& Alexandra Ruth, Bankovic v. Belgium, 97 American Journal of International Law 168, 171 (2003) and Nehal C. Bhuta, Conflicting International Obligations and the Risk of Torture and Unfair Trial: Critical Comments on R (Al-Saadoon and Mufdhi) v. Secretary of State for Defence and Al-Saadoon and Mufdhi v. United Kingdom, 7(5) Journal of International Criminal Justice 1133, 1138 (2009).

42 Ukraine Crisis: Timeline, supra note 4.

43 Crimea Referendum: Voters Back Russia Union, BBC News, 16 March 2014 (Aug. 2, 2018), available at http://www.bbc.co.uk/news/world-europe-26606097.

44 A Treaty between the Russian Federation and the Republic of Crimea on the Accession of the Republic of Crimea to the Russian Federation and on Forming New Constituent Entities within the Russian Federation, Russian Federation-Republic of Crimea, 18 March 2014 (Aug. 2, 2018), available at https:// en.wikisource.org/wiki/Treaty_on_the_Accession_of_the_Republic_of_Crimea_to_Russia.

45 Hague Convention (IV) Respecting the Laws and Customs of War on Land and Its Annex: Regulations Concerning the Laws and Customs of War on Land, 18 October 1907, 205 C.T.S. 277, Art. 42. 
status under international law with the occupier bound to respect the existing laws in force within the territory "unless absolutely prevented" from doing so. ${ }^{46}$ As Carcano notes, this limitation on the occupying power protects the separate existence of the State, its institutions and its laws and constitutes a critical boundary between occupation and annexation. ${ }^{47}$ The fate of occupied territory is typically determined by a peace treaty once the conflict between the parties is resolved..$^{48}$ By contrast annexation describes a domestic legal act of a State purporting to extend sovereignty over a piece of territory over which it has gained effective control through nonconsensual, forcible means. ${ }^{49}$

The exact status of the territory, annexed or occupied, could have a considerable impact in determining which State is responsible for human rights protection within a territory. The situation in Crimea has prompted human rights claims against both Russia and Ukraine at the ECtHR and documents issued by the court state that approximately 4,000 individual applications relating to the events in both Crimea and Eastern Ukraine have been submitted. ${ }^{50}$ Notably, as well as applications being lodged solely against Ukraine or Russia, a number of have been lodged against both states. ${ }^{51}$

46 Hague Convention (IV) Respecting the Laws and Customs of War on Land and Its Annex: Regulations Concerning the Laws and Customs of War on Land, Art. 43. See also Protocol Additional to the Geneva Conventions of 12 August 1949, and relating to the Protection of Victims of International Armed Conflicts, 8 June 1977, 1125 U.N.T.S. 3, Art. 4, which states"neither the occupation of a territory nor the application of the Conventions and this Protocol shall affect the legal status of the territory in question." For an interesting analysis of the genesis of this rule see Eyal Benvenisti, The Origins of the Concept of Belligerent Occupation, 26(3) Law and History Review 621, 648 (2008).

47 Andrea Carcano, The Transformation of Occupied Territory in International Law 24 (Leiden: Brill/Nijhoff, 2015).

48 Id. at 19; this approach is also mentioned by the ECtHR in Al-Skeini and Others v. United Kingdom, supra note 18 , para. 89.

49 Daniel Costelloe, Treaty Succession in Annexed Territory, 65(2) International \& Comparative Law Quarterly 343, 353 (2016); As Fox notes - An assertion of de jure authority through annexation is fundamentally at odds with the temporary nature of occupation - Gregory H. Fox, The Occupation of Iraq, 36 Georgetown Journal of International Law 195, 298 (2004-2005).

50 European Court of Human Rights, Press Country Profile - Ukraine (July 2018) (Aug. 2, 2018), available at https://www.echr.coe.int/Documents/CP_Ukraine_ENG.pdf.

51 European Court of Human Rights, Press Country Profile - Russia (July 2018), at 16 (Aug. 2, 2018), available at http://www.echr.coe.int/Documents/CP_Russia_ENG.pdf. Cases from the east of Ukraine concerning destruction of property as a result of shelling have been brought against both Russia and Ukraine, see Lisnyy v. Ukraine and Russia, Application No. 44913/15, Judgment (Section I), 5 July 2016. Indeed Ukraine itself has launched an inter-State complaint against Russia concerning the annexation of Crimea, which is currently pending before the ECtHR - Ukraine v. Russia (Application No. 20958/14) - see European Court of Human Rights, European Court of Human Rights Communicates to Russia New Inter-State Case Concerning Events in Crimea and Eastern Ukraine, 1 October 2015 (Aug. 2, 2018), available at http:// hudoc.echr.coe.int/app/conversion/pdf?library=ECHR\&id=003-5187816-6420666\&filename=ECHR\%20 communicates $\% 20$ new\%20inter-State $\% 20$ case $\% 20$ concerning $\% 20$ events $\% 20$ in $\% 20$ Crimea\%20 and\%20Eastern\%20Ukraine.pdf; for more analysis of the inter-state case see Koch 2016 and Stefan Kirchner, Interim Measures in Inter-State Proceedings Before the European Court of Human Rights: Ukraine v. Russia, 3(1) University of Baltimore Journal of International Law 33 (2015). 
The fact that these applications have been lodged against both Ukraine and Russia and against each State individually indicates that the duty bearer for human rights obligations in Crimea remains unclear. Two potential scenarios emerge in respect of the situation in Crimea.

\subsection{Scenario 1 - Crimea Has Been Annexed}

The first scenario assumes that Russia's annexation of Crimea is legitimate, and Crimea now forms part of its territory. If this were the case, the responsibility of both Russia and Ukraine for human rights protection in Crimea would be relatively clear.

\subsubsection{Russia's Responsibility for Human Rights}

In order for State responsibility to arise under international law, the conduct consisting of an action or omission must be (a) attributable to the State under international law and (b) it must constitute a breach of the State's international obligations. ${ }^{52}$ Before a State can breach an obligation, the obligation must first be owed..$^{53}$ In the context of the Convention, this means that the applicant must, generally speaking, be within the State's jurisdiction before attribution is determined and State responsibility held to arise. ${ }^{54}$ If Crimea is now de jure part of Russian territory, Russia would be presumed to exercise jurisdiction over this region for the purposes of Article 1 of the ECHR. ${ }^{55}$ This presumption is rebuttable, but it is difficult to rebut in practice. ${ }^{56}$

State responsibility may not arise for every act/omission that occurs within a State's jurisdiction. The State may not be held responsible for the acts of private actors, because those acts may not be attributable to it.. Equally, acts that are attributable to the State may not give rise to State responsibility where the State does not owe obligations to the victims under international law, which is contingent on the exercise

52 James Crawford, Draft Articles on Responsibility of States for Internationally Wrongful Acts, with Commentaries, 2 Yearbook of the International Law Commission 1, 34 (2001).

53 Samantha Besson, The Extraterritoriality of the European Convention on Human Rights: Why Human Rights Depend on Jurisdiction and What Jurisdiction Amounts To, 25(4) Leiden Journal of International Law 857, 867 (2012); O'Boyle 2004, at 130.

54 Crawford 2001, at 35; Milanovic 2008, at 437; occasionally the Court may be required to determine whether the acts of particular soldiers are attributable to the State first before considering the issue of control, see Milanovic \& Papic 2009, at 273.

55 Assanidze v. Georgia, Application No. 71503/01, Judgment (Grand Chamber), 8 April 2004, para. 139, the ECtHR here uses the term competence interchangeably with jurisdiction in this case in para. 137. See also Koch 2016, at 184-185.

56 This is in part down to the international legal principle of territorial integrity see Marcelo G. Kohen, Secession: International Law Perspectives 369 (Cambridge: Cambridge University Press, 2006) and Enrico Milano, Unlawful Territorial Situations in International Law - Reconciling Effectiveness, Legality and Legitimacy 123-125 (Leiden: Brill, 2005).

57 James Crawford \& Simon Olleson, The Nature and Forms of International Responsibility in International Law in International Law 441, 454 (M.D. Evans (ed.), $3^{\text {rd }}$ ed., Oxford: Oxford University Press, 2010). 
of jurisdiction. Determining the issue of attribution of conduct to Russia would also be more straightforward in this scenario. The situation in Crimea is different from other secessionist entities in Europe such as the Moldovan Republic of Transdniestria (MRT) or the Turkish Republic of Northern Cyprus (TRNC). Those entities have declared independence and been supported by another State, Russia and Turkey respectively, however their independence has not been broadly recognised by the international community. This has led to problems with determining who is responsible for protecting human rights within these territories. The supporting States, Russia and Turkey, regularly claim that the actions of the secessionist entities cannot be attributed to Russia and Turkey as they are independent ${ }^{58}$ The ECtHR has often bypassed this issue by ruling that it is not necessary that the supporting State "actually exercises detailed control over the policies and actions" of the authorities of the secessionist entity, ${ }_{15}^{59}$ what matters is that the supporting States exercise effective authority or at the very least have a decisive influence over the secessionist entity which "survives by virtue of the military, economic, financial and political support given to it'by the supporting state.".60 Where the supporting State does this, the actions of the secessionist entity will be attributed to the supporting State with the ECtHR effectively equating the authorities of the secessionist entity with de facto organs or agents of the supporting State for whose acts it may generally be held responsible. ${ }^{61}$

This fraught situation would be avoided in the context of Crimea because, as Russia expressly claims that Crimea is now part of its territory, attributing the conduct of the agents operating there to Russia is not problematic. In sum, if Crimea is genuinely part of the Russian Federation now, the issues of jurisdiction and attribution concerning that State are relatively clear cut.

Catan and Others v. Moldova and Russia, Applications No. 43370/04, 8252/05 and 18454/06, Judgment (Grand Chamber), 19 October 2012, paras. 96-101; Mozer v. Moldova and Russia, Application No. 11138/10, Judgment (Grand Chamber), 23 February 2016, paras. 92-95; Loizidou v. Turkey (Preliminary Objections), supra note 31, para. 54; Cyprus v. Turkey, supra note 35, para. 69.

59 Loizidou v. Turkey (Preliminary Objections), supra note 31, para. 56; Catan and Others v. Moldova and Russia, supra note 58, paras. 106 and 150; llaşcu and Others v. Moldova and Russia, supra note 25, para. 315; Mozer v. Moldova and Russia, supra note 58, para. 157.

Mozer v. Moldova and Russia, supra note 58, para. 157; Cyprus v. Turkey, supra note 35, para. 77; Ilaşcu and Others v. Moldova and Russia, supra note 25, paras. 316 and 392; Catan and Others v. Moldova and Russia, supra note 58, para. 150.

61 Stefan Talmon, The Responsibility of Outside Powers for Acts of Secessionist Entities, 58(3) International \& Comparative Law Quarterly 493, 510-511 (2009); Marek Szydło, Extra-Territorial Application of the European Convention on Human Rights After Al-Skeini and Al-Jedda, 12(1) International Criminal Law Review 271, 281 (2012). The European Commission made a statement on responsibility for de facto state agents in Stocke v. Germany, Application No. 11755/85, Judgment, 19 March 1991: "In the case of collusion between State authorities, i.e. any State official irrespective of his hierarchical position, and a private individual for the purpose of returning against his will a person living abroad, without consent of his State of residence, to its territory where he is prosecuted, the High Contracting Party concerned incurs responsibility for the acts of the private individual who de facto acts on its behalf." 


\subsubsection{Ukraine's Responsibility for Human Rights}

In the document the Ukrainian government sent to the Secretary General of the Council of Europe derogating from the Convention in light of the crisis, the government made a statement concerning human rights responsibility in Crimea. It declared that

Due to the annexation and temporary occupation by the Russian Federation of the integral part of Ukraine - the Autonomous Republic of Crimea and the city of Sevastopol - as a result of armed aggression against Ukraine, the Russian Federation is fully responsible for respect for human rights and implementation of the relevant treaties in annexed and temporary occupied territory of Ukraine. ${ }^{2}$

The statement is confusing and contradictory. The Ukrainian government specifically refers to the Autonomous Republic of Crimea and the city of Sevastopol and makes two conflicting claims, that Russia has annexed this territory and that it is engaged in a "temporary occupation." Ukraine then claims that Russia is "fully responsible" for upholding human rights protection in Crimea. Factually speaking both situations, temporary occupation and annexation depend on the exercise of effective control so there is no issue in that regard. The confusion arises from Ukraine's acknowledgement of annexation and the legal consequences (Russia's responsibility for human rights) flowing from that. In principle, if the territory is now legally part of Russia, Ukraine should cease to have any legal interest in protecting the rights of the population there. The problem is that Russia's annexation has not been internationally recognised and there is a strong case to be made that Russia's annexation violates international law as territory belonging to a State may not be "the object of acquisition by another State resulting from the threat or use of force.".63 In a vote at the UN General Assembly on the subject of the territorial integrity of Ukraine, the vast majority of the States voted in favour of a resolution which stated

the referendum held in the Autonomous Republic of Crimea and the city of Sevastopol on 16 March 2014, having no validity, cannot form the basis

\footnotetext{
62 Ukrainian Government, Resolution of the Verkhovna Rada, supra note 5.

63 United Nations, Charter of the United Nations, 24 October 1945, 1 U.N.T.S. XVI, Art. 2(4); UN General Assembly, Declaration on Principles of International Law Concerning Friendly Relations and Cooperation Among States in Accordance with the Charter of the United Nations, 24 October 1970, A/RES/2625(XXV); Cassese 2005, at 57; Legal Consequences of the Construction of a Wall in Occupied Palestinian Territory, supra note 16, at 171-172. Roth has described Russia's armed takeover of Crimea as an unambiguous violation of international law - Brad Roth, The Neglected Virtues of Bright Lines: International Law in the 2014 Ukraine Crises, 21(2) ILSA Journal of International \& Comparative Law 317, 317 (2014-2015).
} 
for any alteration of the status of the Autonomous Republic of Crimea or of the city of Sevastopol. ${ }^{64}$

It also seems highly unlikely that the ECtHR will recognise the legitimacy of Russia's annexation, given the widespread view that it violates international law. ${ }^{65}$ It could hold Russia responsible for upholding some rights within the territory, but it does not follow that such a finding implicitly legitimises the "annexation." ${ }^{66} \mathrm{In}$ Demopoulos v. Turkey, for example, the ECtHR held that inhabitants of the TRNC were obliged to exhaust domestic remedies created by the authorities of that territory. Despite reaching this finding the court expressly stated

The Court maintains its opinion that allowing the respondent State to correct wrongs imputable to it does not amount to an indirect legitimisation of a regime unlawful under international law. ${ }^{67}$

64 UN General Assembly, Resolution on the Territorial Integrity of Ukraine, 27 March 2014, A/RES/68/262. See also UN General Assembly, Resolution on the Situation of Human Rights in the Autonomous Republic of Crimea and the City of Sevastopol (Ukraine), 19 December 2016, A/RES/71/205 referring to Crimea as temporarily occupied by the Russian Federation and refuting any annexation and UN General Assembly, Resolution on the Situation of Human Rights in the Autonomous Republic of Crimea and the City of Sevastopol, Ukraine, 19 December 2017, A/RES/72/190 urging Russia to comply with its obligations as an occupying power.

The Council of Europe, of which the European Court of Human Rights is a part, issued a resolution through its Parliamentary Assembly stating "the illegal annexation of Crimea by the Russian Federation [has] no legal effect and [is] not recognised by the Council of Europe" - see Parliamentary Assembly of Council of Europe, Resolution 1988 (2014) (Aug. 2, 2018), available at http://assembly.coe.int/nw/ $\mathrm{xml} /$ XRef/Xref-XML2HTML-en.asp?fileid=20873\&lang=en. Another Council of Europe body issued an opinion on the legality of Russia's moves to annex Crimea stating that it amounted to a violation of international law - see European Commission for Democracy Through Law, Opinion on "Whether Draft Federal Constitutional Law No. 462741-6 on Amending the Federal Constitutional Law of the Russian Federation on the Procedure of Admission to the Russian Federation and Creation of a New Subject Within the Russian Federation is Compatible with International Law," 21 March 2014, CDL-AD(2014)004, paras. 39 and 46. See also Thomas Grant, Aggression Against Ukraine Territory, Responsibility, and International Law (New York: Palgrave Macmillan, 2015).

66 Thomas Grant, Crimea After Cyprus v. Turkey: Just Satisfaction for Unlawful Annexation?, EJIL: Talk!, 19 May 2014 (Aug. 2, 2018), available at http://www.ejiltalk.org/crimea-after-cyprus-v-turkey-just-satisfactionfor-unlawful-annexation. The ICJ has held in the past that even if the legitimacy of the administration of a territory is not recognized by the international community, international law can nonetheless recognise the legitimacy of certain acts such as the registration of births, deaths and marriages. The ICJ's primary concern here was for the welfare of the inhabitants of the territory to avoid detrimental effects of occupation - see Legal Consequences for States of the Continued Presence of South Africa in Namibia (South West Africa) notwithstanding Security Council Resolution 276 (1970), Advisory Opinion, 1971 I.C.J. 16, 56.

67 Demopoulos and Others v. Turkey, Applications No. 46113/99, 3843/02, 13751/02, 13466/03, 10200/04, 14163/04, 19993/04, 21819/04, Decision (Grand Chamber), 1 March 2010, para. 96. A former judge at the ECtHR, Loukis Loucaides, was extremely critical of this decision arguing that the ECtHR should not apply the Namibia judgment to human rights remedies in the TRNC - see Loukis Loucaides, Is the European Court of Human Rights Still a Principled Court of Human Rights After the Demopoulos Case?, 24(2) Leiden Journal of International Law 435, 446 (2011). 
Thus, from a legal standpoint, the international community considers that Crimea remains a part of Ukraine and therefore Ukraine's treaty obligations are presumed to extend to this territory, which includes the ECHR. ${ }^{68}$

\subsection{Scenario 2 - Crimea is "Occupied" by Russia}

If the annexation is illegitimate, it means that Russia has not permanently displaced Ukraine's sovereign power over Crimea and the territory is instead subject to a temporary belligerent occupation. In these circumstances, the human rights obligations of both Russia and Ukraine are much less clear.

\subsubsection{Russia's Responsibility for Human Rights}

The ECtHR has stated on several occasions that where States exercise control over foreign territory they can be held responsible for guaranteeing human rights protection there. In Assanidze v. Georgia, the ECtHR stated that

In addition to the State territory proper, territorial jurisdiction extends to any area which, at the time of the alleged violation, is under the "overall control" of the State concerned [...] notably occupied territories. ${ }^{69}$

The ECtHR made similar statements in the case of Al-Skeini v. United Kingdom noting

where the territory of one Convention State is occupied by the armed forces of another, the occupying State should in principle be held accountable under the Convention for breaches of human rights within the occupied territory. ${ }^{70}$

The ICJ has also made similar pronouncements in its opinion on the Democratic Republic of Congo v. Uganda case when it stated

IHRL instruments are applicable in respect of acts done by a state in the exercise of its jurisdiction outside its own territory, particularly in occupied territories. $^{71}$

68 Costelloe 2016 , at 373.

${ }^{69}$ Assanidze v. Georgia, supra note 55, para. 138. The ECtHR made a similar observation in Sargsyan v. Azerbaijan, Application No. 40167/06, Judgment (Grand Chamber), 16 June 2015, para. 94, noting that "the requirement of actual authority [for belligerent occupation] is widely considered to be synonymous to that of effective control [for extra-territorial jurisdiction]."

70 Al-Skeini and Others v. United Kingdom, supra note 18, para. 142.

71 Armed Activities on the Territory of the Congo, supra note 16, at 242-243. See also Legal Consequences of the Construction of a Wall in Occupied Palestinian Territory, supra note 16, at 180. 
The issue here is not in determining that Russia is liable in principle, ${ }^{72}$ but rather in determining the extent of Russia's liability. The nature of the State's jurisdiction is crucial to determining the extent of its human rights obligations under the ECHR. This is because the ECtHR holds the State to different standards depending on whether spatial jurisdiction or personal jurisdiction exists. If spatial jurisdiction is found, the ECtHR requires that the State guarantee all the rights in the Convention, ${ }^{73}$ whereas if personal jurisdiction is found, the ECtHR only requires that the rights that are relevant to the situation be protected. ${ }^{74}$ The jurisprudence on this subject is further complicated by the fact that the ECtHR does not test whether spatial jurisdiction exists consistently. Obvious inconsistencies become apparent when you compare the seminal case of Al-Skeini v. United Kingdom with the more recent case of Chiragov v. Armenia. ${ }^{75}$

Before delving into this comparison, a few observations about the parallels between spatial jurisdiction and belligerent occupation should be made. Firstly, occupied territory is placed under the authority of a hostile army and the occupation only extends to the territory where this authority is established and can be exercised. ${ }^{76}$ Spatial jurisdiction arises where, as a consequence of military action, a contracting State exercises effective control of an area outside its national territory. ${ }^{77}$ The parallels here are very obvious: both rely on the de facto exercise of control/authority outside the normal territory of a State and as such belligerent occupation should automatically give rise to spatial jurisdiction. ${ }^{78}$ Secondly, the ECtHR has stated that when determining whether spatial jurisdiction exists, the primary indicator is the strength of State's military presence in the area. ${ }^{79}$ Secondary indicators it will consider include the "extent to which its military, economic and political support for the local subordinate administration provides it with influence and control over the region." ${ }^{80}$

The overlaps between belligerent occupation and spatial jurisdiction are such that, when a state is in belligerent occupation of a territory, one would expect that the ECtHR will at least test whether spatial jurisdiction exists. With spatial jurisdiction

\footnotetext{
Koch 2016, at 179-180.

73 See, inter alia, Catan and Others v. Moldova and Russia, supra note 58, para. 106.

74 Al-Skeini and Others v. United Kingdom, supra note 18, para. 138.

75 Chiragov v. Armenia, Application No. 13216/05, Judgment (Grand Chamber), 16 June 2015.

76 Hague Convention (IV) Respecting the Laws and Customs of War on Land and Its Annex: Regulations Concerning the Laws and Customs of War on Land, Art. 42.

77 Loizidou v. Turkey (Preliminary Objections), supra note 31, para. 62.

78 Lubell 2012, at 273.

79 Loizidou v. Turkey (Preliminary Objections), supra note 31, paras. 16 and 56; Ilaşcu and Others v. Moldova and Russia, supra note 25, para. 387.

80 Ilaşcu and Others v. Moldova and Russia, supra note 25, paras. 388-394.
} 
offering much greater protection to the inhabitants of the occupied territory, requiring the occupier to guarantee both the positive and negative human rights obligations owed to the applicant or their relatives, its sensible that the ECtHR would conduct such an evaluation rather than default to the lower level of protection offered where the jurisdictional link is personal. Despite this, the trend at the ECtHR has been to apply the spatial jurisdiction test only to cases of prolonged occupation/ de facto annexation. ${ }^{81}$

The inconsistencies in the ECtHR's approach are evident in the Al-Skeini v. United Kingdom case. ${ }^{82}$ In that case, six Iraqi civilians took legal action against the UK. They were all relatives of people who had died in Iraq between May and November 2003 while the UK was in belligerent occupation of Basrah. The UK's soldiers were involved to varying degrees in the deaths and their relatives claimed that the UK had an obligation to investigate them. ${ }^{83}$ Given that the territory was subject to belligerent occupation, one would have expected the ECtHR to find that the UK was exercising spatial jurisdiction over the territory and obliged them to uphold all the ECHR rights. However, the UK government denied that the Convention applied to the occupied territory throughout the litigation. Domestically, the English Court of Appeal ruled that the UK was not exercising effective territorial control over Basrah, even though it was the recognised belligerent occupier there under a UN Security Council Resolution. ${ }^{84}$ In its decision, the Court of Appeal drew comparisons between Turkish control over the TRNC (a case of prolonged occupation/de facto annexation) and UK control over Basrah. The court considered that Turkey intended to exercise control over the TRNC on a long-term basis, Turkey controlled the civilian administration there and had deployed sufficient troops to ensure effective control. By contrast the provisional authority governing Iraq was dominated by American personnel and was "in no sense a subordinate organ or instrument of the UK,"s5 there were not enough

81 See, for example, the TRNC in Loizidou v. Turkey (Preliminary Objections), supra note 31, the Moldovan Republic of Transdniestria in Ilaşcu and Others v. Moldova and Russia, supra note 25 and NagornoKarabakh in Chiragov v. Armenia, supra note 75.

Al-Skeini and Others v. United Kingdom, supra note 18.

83 When an individual has been killed as a result of the use of force by a state agent, the Convention demands some form of effective official investigation - McCann and Others v. United Kingdom, Application No. 18984/91, Judgment, 27 September 1995, para. 161.

84 The UK and US were recognised as belligerent occupiers in UN Security Council, Resolution 1483 (2003), 22 May 2003, S/RES/1483. While this statement has normative power, the fact that occupation is determined by factual control, which changes over time, arguably casts doubt on this statement. The court's view that the ECHR did not apply to the occupied territory was later upheld by the House of Lords - R. (Al-Skeini) v. Secretary of State for Defence [2007] UKHL 26, para. 83.

85 R. (Al-Skeini) v. Secretary of State for Defence [2005] EWCA Civ 1609, para. 118. The UNSCR also specifically noted that the occupiers were "under unified command" and if the court's finding here were taken to its logical conclusion the simple fact of being in a military coalition would mean all occupiers could avoid their responsibilities by claiming they lack exclusive control over the authority administering the territory. 
troops to secure effective control, ${ }^{86}$ and the UK intended to transfer responsibility to Iraqi authorities as soon as possible. ${ }^{87}$ The court denied that holding the status of belligerent occupier equated to effective control stating that "it is a feature of Strasbourg jurisprudence that the court will examine the facts of each particular case to see if the requisite control is in fact exercised." ${ }^{\prime 88}$

In practice the ECtHR has been very inconsistent in its approach to testing the issue of spatial jurisdiction and Al-Skeini offers a potent illustration of this. When the arguments over jurisdiction raised domestically in Al-Skeini came before the ECtHR, it did not even examine whether the UK was exercising spatial jurisdiction. In its judgment, the ECtHR expressly stated

Another exception to the principle that jurisdiction under Art. 1 is limited to a State's own territory occurs when, as a consequence of lawful or unlawful military action, a contracting State exercises effective control of an area outside that national territory [in such circumstances the State must secure] the entire range of substantive rights set out in the Convention. ${ }^{89}$

This paragraph clearly encompasses situations of belligerent occupation and the ECtHR later expressly notes that "the United States and the United Kingdom became occupying powers" in Iraq at the relevant time..$^{90} \mathrm{It}$ also acknowledged that they "exercise[d] powers of government temporarily" in Iraq. ${ }^{91}$ However, the ECtHR did not examine whether the UK was exercising spatial jurisdiction in Iraq.

Instead, the ECtHR modified the rules on personal jurisdiction. Previously, the ECtHR had tended to find personal jurisdiction exclusively on the basis of the connection between a State agent and the victim, such as being in the agent's custody. ${ }^{92}$ The ECtHR denied the possibility that jurisdictional links could arise from instantaneous

${ }^{86}$ R. (Al-Skeini) v. Secretary of State for Defence, supra note 85, para. 121. The judgment is contradictory on this point, the inability to secure effective control amounts to an admission that the UK was not a belligerent occupier of the territory, but this is expressly contradicted in other parts of the judgment see, for example, [12] and [124]. As Milanovic notes, "a belligerent occupation without effective control... is simply no longer an occupation." Milanović 2011, at 146.

R. (Al-Skeini) v. Secretary of State for Defence, supra note 85, para. 116. This final statement should not have any legal weight as all belligerent occupations should be transient, see Carcano 2015, at 22-26 and also Al-Skeini and Others v. United Kingdom, supra note 18, para. 89. The transient nature of the occupation should not be used to cast doubt on its existence, if the ECtHR was prepared to consider that Turkey exercised temporary de facto control over a section of Iraqi territory in Issa and Others $v$. Turkey, Application No. 31821/96, Judgment (Section II), 16 November 2004, para. 74, the UK's presence in Iraq could certainly have amounted to spatial control over territory.

R. (Al-Skeini) v. Secretary of State for Defence, supra note 85, para. 127.

Al-Skeini and Others v. United Kingdom, supra note 18, para. 138.

Id. para. 143.

Id. para. 144.

See, for example, Öcalan v. Turkey (Merits), supra note 40. 
extra-territorial acts of State agents, such as firing missiles that killed civilians. ${ }^{93}$ In Al-Skeini, the ECtHR broadened this considerably in stating that jurisdiction arises when a contracting State "exercises all or some of the public powers normally to be exercised [by the government of the State] ${ }_{1}^{\prime \prime 4}$ and within that context, instantaneous acts may give rise to jurisdictional links to the State. This finding added a layer of governmental operations to a test which had previously been concerned with individual connections. The ECtHR applied this model, which is referred to hereinafter as "personal plus jurisdiction," in Al-Skeini and held that instantaneous acts of UK soldiers, such as shootings, automatically created a jurisdictional link to the State

the United Kingdom, through its soldiers engaged in security operations in Basrah during the period in question, exercised authority and control over individuals killed in the course of such security operations, so as to establish a jurisdictional link between the deceased and the United Kingdom for the purposes of Art. 1 of the Convention. ${ }^{95}$ (emphasis added)

As illustrated below, the key difference between this model and standard personal jurisdiction is that where the State is exercising some public powers, the ECtHR treats the power to kill and the instantaneous act of doing so as "authority and control" over the individual. ${ }^{96}$ So under this conception of the law, the invading State is not obliged to uphold all of the rights under the Convention for the people in the invaded territory, but must secure the rights and freedoms under the Convention that are relevant to the situation of each individual over which the State exercises control and authority. ${ }^{97}$ Lubell has described the court's approach here as "a badly mixed cocktail, unsuccessfully attempting to fuse concepts of control over the territory with the question of state agent authority."198

The approach in Al-Skeini contrasts sharply with the ECtHR's more recent approach in Chiragov v. Armenia. ${ }^{99}$ That case concerned the district of Lachin, which became part of Azerbaijan's territory after the collapse of the Union of Soviet Socialist Republics (USSR). ${ }^{100}$ Armenia and Azerbaijan went to war in the early 90 s over the region of

93

Banković and Others v. Belgium and Others, supra note 28.

Al-Skeini and Others v. United Kingdom, supra note 18, para. 135.

Id. para. 149.

Mads Andenas \& Eirik Bjorge, Human Rights and Acts by Troops Abroad: Rights and Jurisdictional Restrictions, 18(3) European Public Law 473, 480 (2012).

Al-Skeini and Others v. United Kingdom, supra note 18, para. 137.

Lubell 2012, at 321.

Chiragovv. Armenia, supra note 75.

Minsk Agreement establishing the Commonwealth of Independent States, 8 December 1991, Art. 5 states: "the High Contracting Parties acknowledge and respect each other's territorial integrity and the inviolability of existing borders within the Commonwealth." Both Azerbaijan and Armenia signed the treaty on 21 December 1991. 
Nagorno-Karabakh, where Lachin is situated. According to the ECtHR, by the end of 1993 ethnic Armenian forces had gained control over almost the entire territory of Nagorno-Karabakh, including Lachin. ${ }^{101}$ The applicants were displaced by the conflict and brought a case against Armenia inter alia for the loss of peaceful enjoyment of possessions. The ECtHR accepted, as it did previously with Turkey and the TRNC, that the self-proclaimed Nagorno-Karabakh Republic would not exist without the support of Armenia. ${ }^{102}$ Thus, the ECtHR concluded that Armenia was heavily implicated in the belligerent occupation of territory, which de jure belonged to Azerbaijan. The difference in approach between this case and Al-Skeini is stark as the ECtHR states

The Court first considers that the situation pertaining in Nagorno-Karabakh and the surrounding territories is not one of Armenian State agents exercising authority and control over individuals abroad, as alternatively argued by the applicants. Instead, the issue to be determined on the facts of the case is whether the Republic of Armenia exercised and continues to exercise effective control over the mentioned territories and as a result may be held responsible for the alleged violations [...] to determine whether Armenia has jurisdiction in the present case, it is thus necessary to assess whether it exercises effective control over Nagorno-Karabakh and the surrounding territories as a whole. ${ }^{103}$

The ECtHR completely discounts the possibility of personal jurisdiction and assumes that spatial jurisdiction exists in this context. It is not at all clear why the ECtHR should treat these comparable situations of the armed forces of one State entering the territory of another State so differently and why the ECtHR should examine whether spatial jurisdiction exists in one case, but not the other. One possible explanation is that spatial jurisdiction is limited to existing contracting States, though the ECtHR has never acknowledged this to be the case. The ECtHR has shown a desire to avoid gaps in protection in areas currently subject to the Convention's protection and such a limitation would be consistent with that approach. ${ }^{104}$ However, it has also entertained the possibility of spatial jurisdiction existing temporarily in another noncontracting State, ${ }^{105}$ and discounted the idea of there being a limited "legal space" in which the Convention operates. ${ }^{106}$

\footnotetext{
101 Chiragov v. Armenia, supra note 75, para. 174.

102 Id. paras. 172-180.

103 Id. paras. 169-170.

104 Sargsyan v. Azerbaijan, supra note 69, para. 148.

105 Issa and Others v. Turkey, supra note 87, para. 74.

106 Al-Skeini and Others v. United Kingdom, supra note 18, para. 142.
} 
Another possible explanation for the difference in treatment is provided by Giacca who has argued, in the context of economic, social and cultural rights, that a contextual approach should be taken in which "varying levels of obligations" attach to a State "depending on the degree of control exercised in the territory," thus the effectiveness of occupation becomes the determining factor. ${ }^{107}$ This perhaps explains what the Court of Appeal and later the ECtHR were meandering toward in Al-Skeini and it also offers a tempting compromise. Under this approach, as the insurgency in Iraq undermined the effectiveness of the UK's occupation it should have led to fewer obligations being imposed on the UK. Although appealing, the uncertainty this would create over the scope and nature of the applicable obligations is deeply undesirable, especially when States would be asking soldiers in the field to uphold these obligations, which some would contend is already too onerous a burden. Furthermore, even if this is the ECtHR's position, it should not preclude the Court from testing whether spatial jurisdiction exists.

The ECtHR does not explain why it failed to examine whether spatial jurisdiction existed in Al-Skeini and its rationale only becomes apparent in the later Iraq case of Hassan v. United Kingdom.$^{108}$ In that case, the UK tried to deny that a detainee it had captured was within its jurisdiction because he was detained in a US-run facility and therefore the UK did not exercise total and exclusive control over him. ${ }^{109}$ The ECtHR makes some revealing statements about its approach in Al-Skeini, essentially taking the position that because jurisdiction was found on a personal basis there

it was unnecessary to determine whether jurisdiction also arose on the ground that the United Kingdom was in effective military control of South East Iraq during that period. ${ }^{1{ }^{10}}$

Despite noting that the alleged violation in Hassan took place earlier, during the active hostilities phase of the conflict, the Court adopted the same approach

as in Al-Skeini, the Court does not find it necessary to decide whether the United Kingdom was in effective control of the area during the relevant period, because it finds that the United Kingdom exercised jurisdiction over Tarek Hassan on another ground. ${ }^{11}$

\footnotetext{
107 Gilles Giacca, Economic, Social and Cultural Rights in Armed Conflict 161 (Oxford: Oxford University Press, 2014). 
The ECtHR therefore claims it is not necessary to test for spatial jurisdiction when another basis for jurisdiction is apparent. However, another basis for jurisdiction was not clearly apparent in Al-Skeini. The ECtHR had to bend the rules on personal jurisdiction to generate a jurisdictional link to some of the applicants in Al-Skeini. The bending of rules is clear if one of the applicants from Al-Skeini is examined more closely. Mr Hameed Abdul Rida Awaid Kareem's wife was fatally wounded when machine gun fire from outside their building hit their dining room. The UK claimed their soldiers were involved in a firefight with unknown gunmen and the applicant's wife was not the primary target. ${ }^{112}$ As noted above, the ECtHR famously ruled that instantaneous acts, such as firing a missile from a plane, will not give rise personal jurisdiction over the individual hit by the missile. ${ }^{113}$ It is difficult to see how personal jurisdiction was "readily apparent" to the ECtHR in the case of Mrs Kareem when the ECtHR had denied that such jurisdictional links could be created by instantaneous acts in the past.

So where does this leave Russia's responsibilities in Crimea if it is in belligerent occupation of the territory? Russia clearly satisfies the criteria for exercising effective control over the territory, it has deployed many troops, enough to prevent or at the very least deter Ukrainian troops from attempting to re-assert control. ${ }^{114}$ It also has a strong influence on the local administration in Crimea, which is obvious from its successful "annexation."This all points toward Russia exercising spatial jurisdiction in Crimea, however, there is no guarantee that the ECtHR would actually test whether Russia is exercising spatial jurisdiction in Crimea and its obligations there could be similar to those that the ECtHR held the UK to in Al-Skeini. Thus, the degree of responsibility Russia bears there remains unclear and this is linked largely to the ECtHR's inconsistent approach in testing for spatial jurisdiction.

\subsubsection{Is Upholding All Convention Rights in Crimea Feasible?}

As spatial jurisdiction would call for all ECHR obligations to be guaranteed in occupied territory, it is open to question how realistic such a burden would be on a State in the context of an occupation or armed conflict. Guaranteeing all of the rights in the Convention in the context of on-going military operations presents

112 Al-Skeini and Others v. United Kingdom, supra note 18, paras. 43-46.

113 Banković and Others v. Belgium and Others, supra note 28, para. 75. The ECtHR expressly endorsed this conclusion in Medvedyev v. France, Application No. 3394/03, Judgment (Grand Chamber), 29 March 2010, para. 64. Despite some authority that instantaneous acts can create jurisdictional links e.g. Andreou v. Turkey, Application No. 45653/99, Judgment (Section IV), 27 October 2009, many academics view Al-Skeini as re-affirming Bankovic - see, for example, Ryngaert 2012, at 59; Anna Cowan, A New Watershed? Re-evaluating Bankovic in Light of Al-Skeini, 1(1) Cambridge International Law Journal 213, 225 (2012). This issue is discussed further below in the Section 4.2.3 "Pro-Russian Rebels Exercise Control Through Instantaneous Acts."

114 In August 2016 tensions were raised again when Russian authorities accused the Ukraine of attempted incursions into Crimea. Russia Accused Ukraine of Attempted Crimea Incursions, BBC News, 11 August 2016 (Aug. 2, 2018), available at http://www.bbc.co.uk/news/world-europe-37037401. 
significant obstacles for military forces, which could create an unrealistically onerous burden on the State. ${ }^{115}$ Examining the right to life, for example, Watkin argues an automatic investigation into every use of force by State agents is not feasible and that not every death can or should be subject to the exhaustive review process normally associated with the application of peacetime human rights norms. ${ }^{116}$ If the obligation is considered excessive when solely applicable to the use of force by State agents, it will be even more excessive if the State also has to investigate deaths caused by third parties, ${ }^{117}$ which would be required if the State were found to be exercising spatial jurisdiction.

In response many have argued in favour of a functional approach with human rights obligations becoming contingent to some degree on the State's capacity to fulfil them. ${ }^{118}$ The concern is that such an approach generates too much uncertainty in the law because the State's capacity to act may be greater than it realises or is willing to pursue for policy reasons and it generally incentivises States to simply ignore the law claiming they lack the capacity to enforce it. It is imperative that States can identify the applicable obligations ex ante facto, even if the actual burden imposed is mitigated in various ways. Taking the example of spatial jurisdiction, the default position is that all the Convention obligations, positive and negative, substantive and procedural are applicable. However, the full force of these obligations can be mitigated in a variety of ways.

Firstly, it is likely that States can now derogate from the majority of the provisions in the ECHR. ${ }^{119}$ While the practice of Contracting States to the ECHR has not been to derogate from their obligations under the Convention during various military

115 Milanović 2011, at 217; Konstantinos Mastorodimos, The Utility and Limits of International Human Rights Law and International Humanitarian Law's Parallel Applicability, 5 Review of International Law and Politics 123, 137 (2009).

116 Kenneth Watkin, Controlling the Use of Force: A Role for Human Rights Norms in Contemporary Armed Conflict, 98(1) American Journal of International Law 1, 32-33 (2004); The Public Commission to Examine the Maritime Incident of 31 May 2010: Second Report: Israel's Mechanisms for Examining and Investigating Complaints and Claims of Violations of the Laws of Armed Conflict According to International Law (February 2013), at 100-103 (Aug. 2, 2018), available at https://www.gov.il/ BlobFolder/generalpage/alternatefiles/he/turkel_eng_b1-474_0.pdf.

117 House of Commons Defence Committee, UK Armed Forces Personnel and the Legal Framework for Future Operations: Twelfth Report of Session 2013-14 (March 2013), paras. 24 and 25 (Aug. 2, 2018), available at https://publications.parliament.uk/pa/cm201314/cmselect/cmdfence/931/931.pdf.

118 See, for example, Monica Hakimi, State Bystander Responsibility, 21(2) European Journal of International Law 341, 374-376 (2010); Lawson 2011, at 74-75; Yuval Shany, Taking Universality Seriously: A Functional Approach to Extraterritoriality in International Human Rights Law, 7 Law \& Ethics of Human Rights 47 (2013); Moor and Simpson advocate it in the domestic territorial context in Louise Moor \& Brian Simpson, Ghosts of Colonialism in the European Convention on Human Rights, 76(1) British Yearbook of International Law 121, 125 (2005).

119 No derogation is permitted from Articles 3 (prohibition on torture inhuman and degrading treatment or punishment), $4 \S 1$ (prohibition on slavery) and 7 (prohibition on punishment without law). 
operations at home and overseas, ${ }^{120}$ the increasingly frequent applications of the ECHR to extra-territorial military operations give States a powerful incentive to derogate. ${ }^{121}$ The ECtHR has taken a very flexible approach to interpreting Article 15 in practice. ${ }^{122}$ Logically the capacity to derogate should be commensurate with the State's jurisdiction, thus if a State can be obliged to uphold obligations extraterritorially, it should also be permitted to derogate from those obligations extraterritorially. ${ }^{123}$ The case law coming before the ECtHR from conflict situations has broadly tended to focus on two particular rights, protection of the right to life ${ }^{124}$ and the right to liberty and security. ${ }^{125}$ The right to liberty and security (Article 5) is derogable under the Convention. ${ }^{126}$ Derogation from Article 5 would permit States to engage in security detention/internment without having to worry about Article 5 claims. ${ }^{127}$ The Article 2 right to life is also derogable to a limited extent. Article 15 stipulates that States may derogate from Article 2 for lawful acts of war. ${ }^{128}$ This implies

120 Hassan v. United Kingdom, supra note 14, para. 101; Banković and Others v. Belgium and Others, supra note 28 , para. 62.

121 The UK has indicated that it intends to derogate from the Convention during future overseas military operations - UK Ministry of Defence, Government to Protect Armed Forces from Persistent Legal Claims in Future Overseas Operations, 4 October 2016 (Aug. 2, 2018), available at https://www.gov. uk/government/news/government-to-protect-armed-forces-from-persistent-legal-claims-in-futureoverseas-operations.

122 Scott Sheeran, Reconceptualizing States of Emergency Under International Human Rights Law: Theory, Legal Doctrine, and Politics, 34(3) Michigan Journal of International Law 491, 537 (2013).

123 Interestingly in the recent Hassan v. United Kingdom case, the ECtHR expressly referred to the right of States to derogate from Convention rights before noting the UK had not derogated from the Convention while in occupation of Iraq. At no point does the ECtHR say it is not possible for a State to derogate extra-territorially - Hassan v. United Kingdom, supra note 14, para. 98.

124 See, for example, Al-Skeini and Others v. United Kingdom, supra note 18; Jaloud v. Netherlands, supra note 36; Al-Saadoon and Mufdhi v. United Kingdom, Application No. 61498/08, Judgment (Section IV), 2 March 2010.

125 See, for example, Al-Jedda v. United Kingdom, Application No. 27021/08, Judgment (Grand Chamber), 7 July 2011; Hassan v. United Kingdom, supra note 14; Behrami v. France, supra note 19.

126 Although Allain has argued that the right to liberty and right to a fair trial are non-derogable, and as such they now sit beyond the scope of the provisions found in Article 15. Jean Allain, Derogation from the European Convention of Human Rights in the Light of "Other Obligations Under International Law," 5 European Human Rights Law Review 480, 480 (2005).

127 Derogations from the Convention have historically focused on granting States wider powers to detain individuals outside of the strictures of Article 5 - see, for example, Brannigan and McBride v. United Kingdom, Applications No. 14553/89, 14554/89, Judgment, 25 May 1993; Aksoy v. Turkey, Application No. 21987/93, Judgment, 18 December 1996; A. v. United Kingdom, Application No. 3455/05, Judgment (Grand Chamber), 19 February 2009.

128 While the term war naturally implies international armed conflict, there is scope to broaden the definition to include non-international armed conflicts, see Joan Fitzpatrick, Human Rights in Crisis: The International System for Protecting Human Rights During States of Emergency 57 (Philadelphia: University of Pennsylvania Press, 1994); Louise Doswald-Beck, The Right to Life in Armed Conflict: Does International Humanitarian Law Provide all the Answers?, 88(864) International Review of the 
first that Article 2 continues to apply during war (armed conflict) and second, that when a State derogates, Article 2 continues to have some residual effect on unlawful acts of war. If States were to utilise this derogation it would modify the substantive obligation in Article 2 so that only unlawful acts of war were penalised and the focus of the obligation to investigate would also shift to these infringements alone. These unlawful acts of war would be judged against international humanitarian law and international criminal law standards. The beauty of this approach is that when Article 2 is derogated from in this way, it does not impose any additional obligations on the State, but facilitates greater enforcement of other obligations on the State. ${ }^{129}$ The Geneva Conventions, for example, are almost universally ratified and demand that States search for, try or extradite people who are suspected of committing grave breaches of their provisions. ${ }^{130}$ The majority of contracting States to the Convention are also signatories to the Rome Statute of the International Criminal Court, which demands that States investigate and prosecute international crimes, including war crimes, crimes against humanity and genocide..$^{131}$ There is also a very strong argument that States have a duty under customary international law to investigate and prosecute international crimes. ${ }^{132}$ The latent procedural obligations after the State has derogated can be directed toward securing investigation of unlawful acts of war and in this manner IHL and human rights law can complement each other with the Convention providing an accountability framework for violations of IHL. ${ }^{133}$

Red Cross 881, 882 (2006). For a similar discussion in the context of the American Convention on Human Rights see Robert Norris \& Paula Reiton, The Suspension of Guarantees: A Comparative Analysis of the American Convention on Human Rights and the Constitutions of the States Parties, 30 American University Law Review 189, 195 (1980).

129 As Schabas points out, however, the criminal acts under IHL would have to coincide with violations of IHRL for the procedural obligation to investigate to arise - William Schabas, Synergy or Fragmentation? International Criminal Law and the European Convention on Human Rights, 9(3) Journal of International Criminal Justice 609, 622 (2011).

130 Geneva Convention for the Amelioration of the Condition of the Wounded and Sick in Armed Forces in the Field (First Geneva Convention), 12 August 1949, 75 U.N.T.S. 31, Art. 49; Geneva Convention for the Amelioration of the Condition of Wounded, Sick and Shipwrecked Members of Armed Forces at Sea (Second Geneva Convention), 12 August 1949, 75 U.N.T.S. 85, Art. 50; Geneva Convention Relative to the Treatment of Prisoners of War (Third Geneva Convention), 12 August 1949, 75 U.N.T.S. 135, Art. 129; Geneva Convention Relative to the Protection of Civilian Persons in Time of War (Fourth Geneva Convention), 12 August 1949, 75 U.N.T.S. 287, Art. 146.

131 This obligation is implicit in the complementarity principle established in Rome Statute of the International Criminal Court, 17 July 1998, 2187 U.N.T.S. 3, Art. 17. To date only seven Council of Europe States have not ratified the Rome Statute: Armenia, Azerbaijan, Moldova, Monaco, Russia, Turkey, Ukraine.

132 Harmen van der Wilt \& Sandra Lyngdorf, Procedural Obligations Under the European Convention on Human Rights: Useful Guidelines for the Assessment of "Unwillingness" and "Inability" in the Context of the Complementarity Principle, 9 International Criminal Law Review 39, 69 (2009); Louise Doswald-Beck \& Jean-Marie Henckaerts, Customary International Humanitarian Law 607 (Cambridge: Cambridge University Press, 2005).

133 Watkin 2004, at 22-24. 
Secondly, the burden on the State can be mitigated by interpreting the ECHR in line with IHL. The ECtHR has stated on several occasions that Convention articles should be interpreted in line with $\mathrm{IHL} .{ }^{134}$ While the ECtHR has not always been true to this sentiment, ${ }^{135}$ in the recent case of Hassan v. UK, ${ }^{136}$ the Court took a big step toward ensuring that the Convention is interpreted in light of IHL in conflict situations. In that case, the applicant's brother had been detained by UK forces in Basrah while they were in occupation of the territory. The applicant alleged that his detention was arbitrary, unlawful and lacked procedural safeguards in violation of Article 5. There the ECtHR stated "even in situations of international armed conflict, the safeguards under the Convention continue to apply, albeit interpreted against the background of the provisions of international humanitarian law. ${ }^{\prime \prime 13}$ It then proceeded to interpret Article 5 in light of $\mathrm{IHL}$, holding that security detention was permissible under Article 5, but that the legitimacy of the detention must be reviewed by an impartial body, offering fair procedures and ensuring the detention was not arbitrary ${ }^{138}$ Furthermore derogating from Article 2 for lawful acts of war would also force the ECtHR to have recourse to IHL to determine the legality of a given use of force, thereby further encouraging interpretation of the ECHR in light of IHL.

Finally, the ECtHR can interpret the obligations in the Convention flexibly to avoid placing an unreasonable burden on the State. Thus, in Ilaşcu the ECtHR stated that

In determining the scope of a State's positive obligations, regard must be had to the fair balance that has to be struck between the general interest and the interests of the individual, the diversity of situations obtaining in Contracting States and the choices which must be made in terms of priorities and resources. Nor must these obligations be interpreted in such a way as to impose an impossible or disproportionate burden..$^{139}$

It has shown itself willing to do this on several occasions in the past particularly in the context of military operations. In Al-Skeini, for example, the ECtHR stated that

134 Varnava and Others v. Turkey, Applications No. 16064/90, 16065/90, 16066/90, 16068/90, 16069/90, 16070/90, 16071/90, 16072/90 and 16073/90, Judgment (Grand Chamber), 18 September 2009, para. 185; Georgia v. Russia (II), supra note 15, para. 72.

135 In the case of Isayeva $v$. Russia, for example, the ECtHR failed to consider the applicability of IHL in the context of a pitched battle between insurgents and Russian armed forces involving airstrikes and artillery shelling describing the incidents as "a law enforcement operation" - Isayeva v. Russia, supra note 21, para. 180; Philip Leach, The Chechen Conflict: Analysing the Oversight of the European Court of Human Rights, 6 European Human Rights Law Review 732, 733-734 (2008).

136 Hassan v. United Kingdom, supra note 14.

137 Id. para. 104.

138 Id. para. 106.

139 Ilaşcu and Others v. Moldova and Russia, supra note 25, para. 332. See also Treska v. Albania and Italy, Application No. 26937/04, Judgment (Section III), 29 June 2006. 
it would modify the procedural obligations to investigate in the context of a military operation taking into account the "practical problems" investigators face "in a foreign and hostile region in the immediate aftermath of invasion and war" and will apply the procedural obligation "realistically."' ${ }^{140}$ Similarly in the case of Jaloud v. Netherlands, the ECtHR stated that it was

prepared to make reasonable allowances for the relatively difficult conditions under which the Netherlands military and investigators had to work. In particular, it must be recognised that they were engaged in a foreign country which had yet to be rebuilt in the aftermath of hostilities, whose language and culture were alien to them, and whose population [...] clearly included armed hostile elements. ${ }^{141}$

Thus, between derogation, interpretation in light of $\mathrm{IHL}$ and the general flexibility with which the ECtHR is prepared to interpret the ECHR, the burden of upholding all the obligations in Convention can be mitigated both in principle and in practice.

\subsubsection{Ukraine's Responsibility for Human Rights}

If the annexation of Crimea is illegitimate and the belligerent occupation ostensibly temporary, where does this leave Ukraine's obligations in Crimea? Insofar as cases are being brought against both Russia and Ukraine, there are two possible outcomes for Ukraine: the first scenario is that there will be no modification to the Ukraine's human rights obligations in Crimea. The second, more likely scenario, is that the Ukraine will have to uphold some positive obligations from the ECHR in Crimea.

\subsubsection{Loss of Territorial Control with No Impact on Human Rights Obligations}

There are parallels between the Soviet Union's "annexation" of the Baltic States after World War II and the situation in Crimea. When the Soviet Union collapsed in the early 90 s, the Baltic States, Estonia, ${ }^{142}$ Latvia $^{143}$ and Lithuania, ${ }^{144}$ all issued declarations to the effect that they considered their respective States had been subject to belligerent

140 Al-Skeini and Others v. United Kingdom, supra note 18, para. 168.

141 Jaloud v. Netherlands, supra note 36, para. 226.

142 Supreme Council of Estonia, Resolution on the National Independence of Estonia, 20 August 1991 (Aug. 2, 2018), available at http://estonia.eu/about-estonia/history/estonias-return-to-independence19871991.html.

The Constitution of the Republic of Latvia, 19 June 2014, Preamble, states: "The people of Latvia did not recognise the occupation regimes, resisted them and regained their freedom by restoring national independence on 4 May 1990 on the basis of continuity of the State."

144 Supreme Council of the Republic of Lithuania, Act on the Re-establishment of the State of Lithuania, 11 March 1990 -"the execution of the sovereign powers of the State of Lithuania abolished by foreign forces in 1940 is re-established." 
occupation since the end of World War II and that they were re-asserting their sovereignty over their territory. The annexation of these States was never recognised by the wider international community. Currently the international community considers that Crimea remains a part of Ukraine and its ECHR obligations are, therefore, presumed to extend to this territory, unless this presumption is rebutted. ${ }^{145}$ Thus, improbable as it may seem, the ECtHR could rule that Ukraine is obliged to uphold all of its human rights obligations in Crimea. There is some precedent at the ECtHR for the Court to compel a State that has lost control over its de jure territory to uphold all Convention rights as normal within that territory.

In Assanidze v. Georgia, the ECtHR looked at how the presumption of jurisdiction over territory could be rebutted. The case concerned a politician who was detained in the Ajarian Autonomous Republic, which is part of Georgia's territory. The Georgian Supreme Court ordered his release, but the Ajarian authorities refused to release him. The politician took a case against Georgia claiming inter alia that his right to liberty under Article 5 was being infringed. ${ }^{146}$ The ECtHR examined several factors: the fact that Georgia had extended the Convention to the entire territory, it had not issued any reservations to the Convention, the territory had no separatist aspirations and was not subject to the effective overall control of another State. ${ }^{147}$ This final caveat is crucial to our discussion of Crimea. After taking these factors into account, the ECtHR concluded that the presumption was not rebutted. It conducted a similar inquiry into Moldova's control over the MRT in the Ilaşcu case. ${ }^{148}$

Thus, Assanidze establishes the principle that where there is any reason to question the State's de facto control over its de jure territory, the ECtHR will conduct a detailed examination of the prevailing legal and factual elements to determine whether the presumption of jurisdiction has been rebutted. However, that is not always the case with the ECtHR. In Isayeva v. Russia, ${ }^{149}$ there were serious doubts over Russia's de facto control over its de jure territory in Chechnya. The Russian Federation's control over Chechnya was challenged by an entrenched insurgency there. In October 1999, Grozny was under the control of Chechen insurgents who launched attacks on the Russian armed forces. ${ }^{150}$ Russia had clearly lost de facto control over Grozny and laid siege to the city in order to regain control. Russia established a safe exit route for civilians in Grozny to escape from the fighting. However, the Russian armed

145 Costelloe 2016, at 373.

146 Assanidze v. Georgia, supra note 55, para. 151.

147 Id. paras. 140-142.

148 The ECtHR looked at whether reservations had been issued in Ilaşcu and Others v. Moldova and Russia, supra note 25, para. 324, and the existence of secessionist entities on the territory in para. 325.

149 Isayeva v. Russia, supra note 21.

150 William Abresch, A Human Rights Law of Internal Armed Conflict: The European Court of Human Rights in Chechnya, 16(4) European Journal of International Law 741, 754 (2005). 
forces launched an air attack on the civilians as they fled. The applicant lost family members in the attack and brought a case against Russia. The ECtHR itself implicitly acknowledged that Russia had lost control over the area stating "[t]he situation in Chechnya had called for exceptional measures on behalf of the State in order to regain control over the Republic and to suppress the illegal armed insurgency" (emphasis added). ${ }^{151}$

The ECtHR had also previously stated in Ilaşcu that:

jurisdiction is presumed to be exercised normally throughout the State's territory. This presumption may be limited in exceptional circumstances, particularly where a State is prevented from exercising its authority in part of its territory. That may be as a result of military occupation by the armed forces of another State which effectively controls the territory concerned, acts of war or rebellion, or the acts of a foreign State supporting the installation of a separatist State within the territory of the State concerned. ${ }^{152}$ (emphasis added)

Despite the acknowledgement by the ECtHR that control had been lost in Isayeva and that the presumption of control could be "limited" by "acts of rebellion" in Ilaşcu, the ECtHR did not conduct any inquiry into whether the presumption that Russia controlled Grozny was rebutted, as it had in Assanidze. Nor did it modify the obligations that Russia owed to the civilians in Grozny in line with Ilaşcu and other cases..$^{153}$ The ECtHR obliged Russia to uphold the positive obligation to investigate the deaths in this case, ${ }^{154}$ and the positive obligation to protect the right to life of the applicant and her relatives. ${ }^{155}$

The disparities between these cases suggest that the ECtHR is not holding States in comparable situations to the same standards, nor is it consistently assessing whether the presumption of jurisdiction is rebutted of its own volition where this is apparent. There are numerous possible reasons for this. First, Russia did not actively deny that it was capable of exercising jurisdiction in Chechnya. In many cases where a State actively denies that it is exercising jurisdiction, the ECtHR holds the State to a corresponding lower level of obligations. ${ }^{156}$ Secondly, it has been argued that

151 Isayeva v. Russia, supra note 21, para. 178.

152 Ilaşcu and Others v. Moldova and Russia, supra note 25, para. 312.

153 See the ECtHR's findings in cases like Catan and Others v. Moldova and Russia, supra note 58 and Ivantoc and Others v. Moldova and Russia, Application No. 23687/05, Judgment (Section IV), 15 November 2011.

154 Isayeva v. Russia, supra note 21, para. 224.

155 Id. para. 201.

156 Ilaşcu and Others v. Moldova and Russia, supra note 25; Catan and Others v. Moldova and Russia, supra note 58; Azemi v. Serbia, Application No. 11209/09, Judgment (Section II), 5 November 2013; Jularic v. Croatia, Application No. 20106/06, Judgment (Section I), 20 January 2011. 
where a secessionist entity lacks the support of another State, it cannot rebut the presumption of jurisdiction. ${ }^{157}$ This distinction is crucial. As the Chechen separatists were not backed by another State, there was no other State to assume the mantle of human rights protection in Chechnya, it would have resulted in a lacuna in the Convention's protection if the ECtHR held that Russia was not responsible, ${ }^{158}$ a lacuna the ECtHR was obviously keen to avoid. Thus, unless a secessionist entity is supported by another State, there is no other party available to assume the duty to guarantee human rights within the territory and the ECtHR is less likely to reduce the obligations on the State losing control over the territory. ${ }^{159}$

This interpretation of the law was expressly confirmed in Sargsyan v. Azerbaijan..$^{160}$ That case revolved around the village of Gulistan, which was situated on the line of contact between Azerbaijan and Armenia in their protracted dispute over the Nagorno-Karabakh region. Several villagers were displaced from their homes in Gulistan by the conflict and sought compensation for their loss of property as the village was effectively in no man's land between the two armies. Azerbaijan claims the village is part of its de jure territory and its armed forces occupied the village, but they have been surrounded by Armenian troops in a strategically superior position for many years and the area is surrounded by mines. Azerbaijan argued that they should not be obliged to uphold full human rights obligations in the Convention in disputed zones or "areas which are rendered inaccessible by the circumstances." ${ }^{\text {"161 }}$ While the ECtHR accepted that Azerbaijan "may encounter difficulties at a practical level in exercising their authority in the area of Gulistan,"162 this did not alter their human rights obligations there. Gulistan remained subject to the de facto control of the Azerbaijani government and as a result the presumption that it exercised jurisdiction there was not displaced. It noted that the State's responsibility has only been limited in previous cases when another State or separatist regime exercises effective control over the territory. ${ }^{163}$ The ECtHR referred to the "need to avoid a vacuum in Convention

157 Kjetil Mujezinovic Larsen, Territorial Non-Application of the European Convention on Human Rights, 78 Nordic Journal of International Law 73, 82-83 (2009).

158 Note the ECtHR's desire to avoid any such gaps in protection in other cases such as Banković and Others v. Belgium and Others, supra note 28, para. 78; Al-Skeini and Others v. United Kingdom, supra note 18, para. 142; Bijelic v. Montenegro and Serbia, Application No. 11890/05, Judgment (Section II), 28 April 2009.

159 For a thorough discussion of the human rights obligations of de facto entities see Anthony Cullen \& Steven Wheatley, The Human Rights of Individuals in De Facto Regimes Under the European Convention on Human Rights, 13 Human Rights Law Review 691 (2013). Sargsyan v. Azerbaijan, supra note 69, para. 94.

161 Id. para. 146.

162 Id. para. 150.

163 Id. para. 140. 
protection, ${ }^{\prime \prime 64}$ which could be caused by creating an exception like that suggested by Azerbaijan. It therefore ruled that Azerbaijan continued to exercise jurisdiction there for the purposes of the Convention, even though Azerbaijan had such limited control over the territory. Thus, while it is conceivable that Ukraine could be obliged to uphold all the Convention obligations in Crimea (notwithstanding the derogations it has proclaimed), the fact that the Crimean separatists are backed by Russia reduces the practical possibility of this.

\subsubsection{Positive Obligations}

The second, more likely, albeit much more complicated, scenario is that Ukraine is obliged to uphold some of its Convention obligations in Crimea. It stands to reason that if spatial jurisdiction for the purposes of the ECHR can be acquired over territory occupied and controlled, spatial jurisdiction can be lost over territory where control is ceded such that the ECHR obligations are reduced or removed entirely. Yet when a State loses de facto control over its territory, uncertainty arises over the obligations the State owes. In Ilaşcu v. Moldova and Russia ${ }^{165}$ which is comparable in many respects to the situation in Crimea, the ECtHR examined a situation where a State had lost de facto control over its de jure territory. Moldova was part of the USSR until it collapsed in the 1990s. Moldova declared independence in 1991 and claimed Transdniestria as part of its territory. Transdniestria was part of the Moldavian Soviet Socialist Republic, which was succeeded by the Moldovan State. After the USSR collapsed, its fourteenth army remained in Transdniestria and declared independence as the "Moldavian Republic of Transdniestria" (MRT) in 1991. Akin to Crimea, the MRT has not been internationally recognised as an independent State. ${ }^{166}$ Moldova continues to claim Transdniestria as part of its de jure territory, despite its inability to exercise de facto control there for decades. The ECtHR has addressed similar situations where the State in de jure control fails to exercise de facto control. ${ }^{167}$

The four applicants in Ilaşcu were arrested in the MRT in 1992 and charged with offences, including murder and "anti-Soviet activities."They were tried and sentenced by the Supreme Court of the MRT and detained for a number of years. They also alleged that numerous violations of the Convention had arisen from their trial and detention and sought to hold Russia and Moldova responsible. They claimed that Moldova should have interceded with the MRT to stop the Convention violations

164

165

166

167

Sargsyan v. Azerbaijan, supra note 69, para. 148.

Ilaşcu and Others v. Moldova and Russia, supra note 25.

Id. paras. 28-41.

Cypriot control over the Turkish Republic of Northern Cyprus in Cyprus v. Turkey, supra note 17; Georgian control over South Ossetia and Abkhazia in Georgia v. Russia (II), supra note 15; Azerbaijani and Armenian control over different parts of Nagorno-Karabakh in Sargsyan v. Azerbaijan, supra note 69 and Chiragov v. Armenia, supra note 75. 
arising from their detention. They alleged that Russia was exercising jurisdiction in the MRT because it exercised de facto control over the area and should therefore be held responsible for the Convention violations. ${ }^{168}$ Our focus here is on how the Court treated Moldova's jurisdiction over the MRT. The ECtHR ruled that the Moldovan government was the only legitimate government of the Republic of Moldova under international law, but that it did not exercise authority over the MRT. ${ }^{169}$ This is similar in many respects to the situation in Crimea where Russia's "annexation" has not been recognised internationally and with Crimea being perceived as a continuing part of Ukrainian territory over which it has lost control. ${ }^{170}$ However, the lack of control over this territory was not a barrier to Moldova exercising jurisdiction for the purposes of Article 1. The ECtHR stated

where a Contracting State is prevented from exercising its authority over the whole of its territory by a constraining de facto situation [...] it does not thereby cease to have jurisdiction within the meaning of Art. 1 of the Convention over that part of its territory [...] such a factual situation reduces the scope of that jurisdiction in that the undertaking given by the State under Article 1 must be considered by the Court only in the light of the Contracting State's positive obligations towards persons within its territory. The State in question must endeavour, with all the legal and diplomatic means available to it vis-à-vis foreign States and international organisations, to continue to guarantee the enjoyment of the rights and freedoms defined in the Convention. ${ }^{171}$

The scope of Moldova's jurisdiction was reduced so that it was only obliged to uphold its positive obligations. Thus, the Ukrainian government's assertion that the Russian Federation is "fully responsible" for upholding Convention rights in the "annexed" territory does not match the ECtHR's jurisprudence as Ukraine is, at the very least, partially responsible for upholding positive obligations in Crimea.

The exact positive obligations Moldova had to uphold in the MRT, and by extension Ukraine in Crimea, are extremely unclear. The very notion that States can owe positive obligations when they are not exercising de facto control has been

168 It is worth noting, in the context of our discussion of Crimea, that the ECtHR determined in Ilascu that Russia could be held responsible for what happened in the MRT because it provided military, economic, financial and political support to the territory. By virtue of its receiving this support, the territory remained under the effective authority, or at the very least under the decisive influence, of the Russian Federation - Ilaşcu and Others v. Moldova and Russia, supra note 25, para. 392. Id. para. 330.

170 Kirchner argues that Russia's aim in encouraging the creation of self-proclaimed independent "States" in Moldova, Georgia and now Ukraine is to de-stabilize these countries to the point where NATO membership and EU membership becomes impossible - Kirchner 2015, at 42.

171 Ilaşcu and Others v. Moldova and Russia, supra note 25, para. 333. 
questioned..$^{172}$ On the one hand, the ECtHR implies that the State must "take the diplomatic, economic, judicial or other measures that it is in its power to take and are in accordance with international law to secure to the applicants the rights guaranteed by the Convention. ${ }^{\prime \prime 73}$ On the other hand, it has stated

Although it is not for the Court to indicate which measures the authorities should take in order to comply with their obligations most effectively, it must verify that the measures actually taken were appropriate and sufficient in the present case. When faced with a partial or total failure to act, the Court's task is to determine to what extent a minimum effort was nevertheless possible and whether it should have been made. ${ }^{174}$

Thus, it is unclear whether the State must take "all the measures within its power" - diplomatic, economic, judicial - or simply undertake a "minimum effort." The ECtHR ruled that Moldova had positive obligations to re-establish control over its territory and to take measures to ensure the applicants' rights, $^{175}$ holding that Moldova had failed to make sufficient efforts to secure the release of the detainees, because it had not raised the issue during negotiations with Russia over the MRT. ${ }^{176}$ Leaving aside the discomfort generated by the ECtHR dictating the foreign policy of an independent State, the ECtHR has failed to clarify the scope and content of these positive obligations in subsequent cases.

In Ivantoc and Others v. Moldova and Russia, ${ }^{177}$ the ECtHR seemed to follow an "all measures within its power" approach. In that case, several of the applicants in Ilaşcu sought to hold Moldova responsible for not doing all they could to secure their Convention rights. The ECtHR held Moldova had discharged its positive obligation as it had "constantly raised the issue of the applicants' fate in their bilateral relations with the Russian Federation" and continually sought assistance from international organisations and other States. ${ }^{178}$ By contrast, the ECtHR seemed to follow the "minimum effort"

172 Michal Gondek, Extraterritorial Application of the European Convention on Human Rights: Territorial Focus in the Age of Globalization?, 52 Netherlands International Law Review 349, 368 (2005). Hampson argues that certain positive obligations require the kind of control a state only has over its own territory before they can be fulfilled - Francoise Hampson, Direct Participation in Hostilities and the Interoperability of the Law of Armed Conflict and Human Rights Law, 87 International Law Student Series US Naval War Collection 187, 189 (2011). Ilaşcu and Others v. Moldova and Russia, supra note 25, para. 331.

174 Id. para. 334.

175 Id. para. 339.

176 Id. para. 349.

177 Ivantoc and Others v. Moldova and Russia, supra note 153.

178 Id. para. 109. 
approach in Catan and Others v. Moldova and Russia. ${ }^{179}$ In that case, the MRT had banned the use of Latin script in schools, forcibly evicting students from their classes and forcing them to attend special schools. When the applicants complained that Moldova had not protected their right to education and should have raised this issue diplomatically with Russia, ${ }^{180}$ the ECtHR held that Moldova had satisfied its positive obligation by refurbishing the new schools, paying their rent and covering other costs of running them. ${ }^{181}$ More recently in Mozer v. Moldova and Russia, ${ }^{182}$ the applicant, a German national, had been detained by the MRT and complained inter alia that his detention was unlawful. The ECtHR reverted to the test in Ilaşcu stating that Moldova had to "use all the legal and diplomatic means available to it to continue to guarantee the enjoyment of the rights and freedoms defined in the Convention to those living [in the MRT]."133 The ECtHR eventually concluded that Moldova had satisfied its positive obligations because it had appealed to intergovernmental organisations and other countries, including Russia, to assist in securing the applicant's rights. ${ }^{184}$

In sum, the extent of the Ukraine's positive obligations toward Crimea remain unclear in light of the ECtHR's jurisprudence. It is unclear whether Ukraine has an obligation to do everything diplomatically, economically and legally within its power to secure the rights of the individuals in Crimea or whether the Ukraine is only obliged to undertake a minimum effort to secure their rights.

\subsection{Conclusion on Crimea}

To conclude our analysis of jurisdiction between Ukraine and Russia in Crimea, the situation is deeply unclear. The ECtHR could determine that Russia is obliged to uphold all the Convention obligations in Crimea and has full spatial jurisdiction, as it has with territories such as the TRNC in Loizidou. This outcome would lead to a higher level of human rights protection for the inhabitants of Crimea (all positive and negative Convention obligations) and be much clearer for the State. However, it is entirely possible that the ECtHR will find that jurisdictional links only arise in Crimea under the personal jurisdiction model, discussed further below, or something in between full spatial jurisdiction and personal jurisdiction, such as the personal plus jurisdiction discussed above and set out in Al-Skeini. The consequences of these different approaches can lead to wildly different levels of obligation on the State. For example, a State with full spatial jurisdiction would have to investigate every

\footnotetext{
179 Catan and Others v. Moldova and Russia, supra note 58.

$180 \quad$ Id. para. 129.

181 Id. paras. 147 and 148.

182 Mozer v. Moldova and Russia, supra note 58.

183 Id. para. 100.

184 Id. paras. 153-155.
} 
death occurring in a given territory, including those caused by third parties, whereas jurisdiction arising under the personal jurisdiction model would only oblige the State to investigate deaths where a State agent was directly involved or implicated.

The Ukraine's ECHR obligations with respect to Crimea are perhaps even less clear. Ukraine may be obliged to uphold all its ECHR obligations with respect to Crimea, though it is perhaps more likely that it will only be obliged to uphold positive obligations under the Convention there. The exact scope and extent of these positive obligations remains unclear in the ECtHR's jurisprudence, with the Court oscillating between demanding that the State do everything in its power to resolve a human rights complaint in some cases and engage in a minimum effort to resolve complaints in others. The uncertainty surrounding each State's obligations with respect to Crimea is obviously deeply unsatisfactory for both the State and potential victims of human rights abuses. The Court can improve the situation by consistently testing whether spatial jurisdiction exists in these scenarios and assessing whether the presumption of jurisdiction is rebutted when a State's de facto control is at issue.

While the distribution of human rights responsibilities in Crimea is deeply uncertain, the annexation itself was relatively straightforward with one commentator describing the operation as "the smoothest invasion of modern times." ${ }^{\prime 15}$ The relative ease with which Russia annexed Crimea is a stark contrast to the entrenched military conflict on-going in Eastern Ukraine. In early March 2014, Russian troops amassed along Ukraine's eastern border. ${ }^{186}$ In April, pro-Russian separatists seized control of towns within the Donetsk and Luhansk regions and declared their independence. ${ }^{187}$ The Ukrainian military responded by driving the rebels out of the city of Slavyansk and encircling the de facto capital of Donetsk. The violence escalated throughout the summer months, most notably contributing to the shooting down of Malaysian Flight MH17. ${ }^{188}$ An Organisation for Security and Co-operation in Europe (hereinafter OSCE) monitored ceasefire signed in September was short-lived as the conflict

185 John Simpson, Russia's Crimea Plan Detailed, Secret and Successful, BBC News, 19 March 2014 (Aug. 2, 2018), available at http://www.bbc.co.uk/news/world-europe-26644082.

Laura Smith-Spark et al., What Do We Know About Russia's Troop Buildup on Ukraine's Border?, CNN, 28 March 2014 (Aug. 2, 2018), available at http://edition.cnn.com/2014/03/28/world/europe/russiaukraine-troop-buildup; Jon Swaine, Russian Troops May Be Massing to Invade Ukraine, Says White House, The Guardian, 23 March 2014 (Aug. 2, 2018), available at https://www.theguardian.com/ world/2014/mar/23/russian-troops-may-invade-ukraine-white-house.

For further context on the conflict see Reeves \& Wallace 2015, at 365-372.

188 Kashmira Gander, Malaysia Airlines Flight MH17 Crash: Nine Britons, 23 Americans and 80 Children' Feared Dead After Boeing Passenger Jet Is "Shot Down" Near Ukraine-Russia Border, The Independent, 17 July 2014 (Aug. 2, 2018), available at http://www.independent.co.uk/news/world/europe/malaysiaairlines-plane-crash-boeing-jet-carrying-295-people-crashes-in-ukraine-9612882.html; Sabrina Tavernise et al., Jetliner Explodes over Ukraine; Struck by Missile, Officials Say, New York Times, 17 July 2014 (Aug. 2, 2018), available at http://www.nytimes.com/2014/07/18/world/europe/malaysianairlines-plane-ukraine.html?_r=0. 
continued into the autumn and winter. ${ }^{189}$ After a significant increase in violence at the turn of the year, a second ceasefire was signed in February 2015. ${ }^{190}$ There have been numerous military engagements and severe human rights violations since this ceasefire was signed. Unlike in Crimea, in Eastern Ukraine the Russian government has consistently refused to acknowledge that it is playing a role in the conflict. ${ }^{191}$

This section considers the human rights obligations that Ukraine and Russia owe to individuals within the eastern regions of the country. ${ }^{192}$ The factual profile of the violence in Eastern Ukraine makes the pursuit of enforceable human rights obligations more complex. Primarily this is because there are three main actors in the conflict: 1) pro-Russian rebels, purportedly in receipt of continuing support from the Russian Federation; 2) the Ukrainian armed forces and security services; 3) proUkrainian volunteer groups. Thus, in addition to navigating the ECtHR's inconsistent approach to jurisdiction, those alleging human rights abuses arising from the conflict will also be required to demonstrate that the perpetrator's actions can be attributed to either the Ukrainian or Russian State.

\section{Ukraine's Responsibility for Human Rights}

This section addresses both the questions of attribution and jurisdiction with regard to Ukraine's human rights responsibilities. When addressing the issue of

Organization for Security and Co-operation in Europe, Protocol on the Results of Consultations of the Trilateral Contact Group, signed in Minsk, 5 September 2014 (Aug. 2, 2018), available at http://www. osce.org/home/123257. See also Organization for Security and Co-operation in Europe, Memorandum of 19 September 2014 Outlining the Parameters for the Implementation of Commitments of the Minsk Protocol of 5 September 2014, 19 September 2014 (Aug. 2, 2018), available at http://www. osce.org/home/123806.

190 Matthew Weaver \& Alec Luhn, Ukraine Ceasefire Agreed at Belarus Talks, The Guardian, 12 February 2015 (Aug. 2, 2018), available at https://www.theguardian.com/world/2015/feb/12/ukraine-crisis-reportsemerge-of-agreement-in-minsk-talks; Minsk Agreement on Ukraine Crisis: Text in Full, The Telegraph, 12 February 2015 (Aug. 2, 2018), available at http://www.telegraph.co.uk/news/worldnews/europe/ ukraine/11408266/minsk-agreement-on-ukraine-crisis-text-in-full.html.

191 When asked in April 2014 whether there were Russian soldiers in Eastern Ukraine Vladimir Putin stated: "Nonsense. There are no Russian units in eastern Ukraine - no special services, no tactical advisors. All this is being done by the local residents, and the proof of that is the fact that those people have literally removed their masks." President of Russia, Direct Line with Vladimir Putin, 17 April 2014 (Aug. 2, 2018), available at http://en.kremlin.ru/events/president/news/20796. A year later in April 2015 Putin reiterated this denial: "Finally, the question of whether Russian troops are present in Ukraine... I can tell you outright and unequivocally that there are no Russian troops in Ukraine." President of Russia, Direct Line with Vladimir Putin, 16 April 2015 (Aug. 2, 2018), available at http://en.kremlin.ru/events/ president/news/49261. He has since qualified this by conceding that Russian military intelligence officers were operating on Ukrainian territory. Shaun Walker, Putin Admits Russian Military Presence in Ukraine for First Time, The Guardian, 17 December 2015 (Aug. 2, 2018), available at https://www. theguardian.com/world/2015/dec/17/vladimir-putin-admits-russian-military-presence-ukraine.

192 The regions under which pro-Russian rebels exercise influence are Donetsk and Luhansk. Rebels in both regions have defined themselves as "People's Republics." OHCHR Report June 2016, supra note 9 , at $4-5$. 
attribution in previous cases, the ECtHR has naturally looked to the definitions of State Responsibility found in public international law. This approach was recognised in the case of Behrami where the Court recalled that

the principles underlying the Convention cannot be interpreted and applied in a vacuum. It must also take into account relevant rules of international law when examining questions concerning its jurisdiction and, consequently, determine state responsibility in conformity and harmony with the governing principles of international law of which it forms part, although it must remain mindful of the Convention's special character as a human rights treaty. ${ }^{193}$

The position is relatively straightforward with regard to attributing responsibility for actions conducted by Ukrainian military, police and security forces in Eastern Ukraine who are engaged in their "anti-terrorism" operation against pro-Russian groups. ${ }^{194}$ In such situations, these are State agents acting on behalf of their government, which gives rise to their responsibility under the Convention.

The situation is less clear where the actions of armed groups not directly affiliated with either State are concerned. These are not individuals who make up the organs of the State, but instead those whose conduct may be directed or controlled by the State. This is dealt with under Article 8 of the Articles on State Responsibility which states

The conduct of a person or group of persons shall be considered an act of a State under international law if the person or group of persons is in fact acting on the instructions of, or under the direction or control of, that State in carrying out the conduct. ${ }^{195}$

The requirements that an individual or group is operating on the "instructions," following the "direction," or under the "control" of the State, are to be read disjunctively. ${ }^{196}$ Thus attribution will arise if any one of these three factors is established. Within this rule the notions of instruction and direction are readily intelligible and arguably set quite a high standard for when action can be attributed to the State. ${ }^{197}$

193 Behrami v. France, supra note 19, para. 122.

194 Ukraine Says Donetsk “Anti-Terror Operation” Under Way, BBC News, 16 April 2014 (Aug. 2, 2018), available at http://www.bbc.co.uk/news/world-europe-27035196.

Draft Articles on State Responsibility, Crawford 2001, Art. 8. Article 4-11 of the Draft Articles of State Responsibility are now considered to reflect customary international law. See also Stocke v. Germany, supra note 61 which confirms this approach to the law. Crawford 2001, at 48.

197 The intention of which is to identify "the existence of a real link between the person or group performing the act and the State machinery." Crawford 2001, at 47. 
As with the test for control over individuals or territory, the definition of control of an armed group is often seen as being less certain and thus more flexible. Nonetheless, while necessarily being dependent on the facts of each given allegation of abuse, a strong case could be made that Ukrainian volunteer battalions who commit human rights abuses could have their conduct attributed to the Ukrainian State. The OHCHR Special Mission to Ukraine has noted that the structure of the Ukrainian security operation aimed at regaining control of the eastern regions of Donetsk and Luhansk "involves the army, the military police (National Guard), the National Security Service (SBU) and volunteers' battalions."198 The presence of these volunteer battalions within the wider organisational arrangement of this operation denotes that the volunteers are most likely following the direction, or acting on the instructions, of the Ukrainian State so as to engage Article 8 of the Articles on State Responsibility. ${ }^{199}$

Despite the ease with which this attribution question may be resolved there remains a high degree of uncertainty over whether Ukraine exercises sufficient jurisdiction, as it is understood in Article $1 \mathrm{ECHR}$, over its eastern regions for its human rights obligations to apply. On analysis two possible interpretations emerge.

\subsection{Scenario 1 - Ukraine Exercises Jurisdiction Throughout Its Territory}

The first interpretation of Ukraine's human rights responsibilities is to follow the ECtHR's basic presumption that the application of the Convention is "primarily territorial," and thus Ukraine owes human rights obligations throughout its entire territory. This interpretation came to the fore in the Court's jurisprudence following the 2001 case of Banković. ${ }^{200}$ In Banković, the Court relied heavily on public international law principles of State jurisdiction holding that the Convention's application is "primarily territorial"201 and that jurisdiction would only arise extra-territorially in exceptional circumstances which were "subordinate to that State's and other states'

198 Office of the United Nations High Commissioner for Human Rights, Report on the Human Rights Situation in Ukraine - 15 July 2014, 15 July 2014, at 3 (Aug. 2, 2018), available at http://www.ohchr. org/Documents/Countries/UA/Ukraine_Report_15July2014.pdf.

Crawford 2001, Art. 8. The Ukrainian position also falls squarely within the example provided in the following commentary on the Draft Articles of State Responsibility: "Most commonly, cases of this kind will arise where State organs supplement their own action by recruiting or instigating private persons or groups who act as 'auxiliaries' while remaining outside the official structure of the State. These include, for example, individuals or groups of private individuals who, though not specifically commissioned by the State and not forming part of its police or armed forces, are employed as auxiliaries or are sent as 'volunteers' to neighbouring countries, or who are instructed to carry out particular missions abroad." Crawford 2001, at 47.

Banković and Others v. Belgium and Others, supra note 28, para. 59.

201

The Court went on to state that: "While international law does not exclude a state's exercise of jurisdiction extra-territorially, the suggested bases of such jurisdiction (including nationality, flag, diplomatic and consular relations, effect, protection, passive personality and universality) are, as a general rule, defined and limited by the sovereign territorial rights of the other relevant states." Id. 
territorial competence.".202 This approach has been followed repeatedly by the ECtHR since. ${ }^{203}$ It simplifies the application of the Convention insofar as Eastern Ukraine is concerned, however - as demonstrated above - there is the possibility that Ukraine can rebut the presumption that it exercises sufficient control over some of its territory so as to limit its obligations. This is an avenue which Ukraine would be likely to take given the derogation which it filed in 2015 where it stated

In view of armed aggression of the Russian Federation against Ukraine involving both regular Armed Forces of the Russian Federation and illegal armed groups guided, controlled and financed by the Russian Federation, an anti-terrorist operation is being conducted by the units of the Security Service of Ukraine, the Ministry of Internal Affairs of Ukraine and the Armed Forces of Ukraine since April 2014, on the territory of certain areas of the Donetsk and Luhansk oblasts of Ukraine. The anti-terrorist operation is a part of the inalienable right of Ukraine to individual self-defense against aggression according to Article 51 of the UN Charter. The Russian Federation, which actually occupies and exercises control over certain areas of the Donetsk and Luhansk oblasts, is fully responsible for respect for and protection of human rights in these territories under international humanitarian law and international human rights law. ${ }^{204}$

That argument would be strengthened when one looks at the factual circumstances in Eastern Ukraine as presented in the case of Lisnyy v. Ukraine and Russia, the first case considering the conflict to be resolved by the ECtHR. The application was brought against both Ukraine and Russia by three residents of the Donetsk and Luhansk regions whose homes had been either damaged or

202 Banković and Others v. Belgium and Others, supra note 28, para. 60. The Grand Chamber in Banković had relied on the following passage in the Soering case to make this statement: "Article 1 of the Convention, which provides that 'the High Contracting Parties shall secure to everyone within their jurisdiction the rights and freedoms defined in Section I,' sets a limit, notably territorial, on the reach of the Convention." Soering v. the United Kingdom, Application No. 14038/88, Judgment, 7 July 1989, para. 86. It should be noted that this statement was made in a judgment of July 1989 and was not reiterated in the jurisprudence concerning Article 1 until the Banković case twelve years later, suggesting a high degree of selectivity in the Court's use of its own principles. For instance, it was not mentioned in the most significant jurisdiction case heard in the interim Loizidou v. Turkey (Preliminary Objections), supra note 31.

203 See, for instance, Hirsi Jamaa v. Italy, supra note 28, para. 71, where the Court referred to jurisdiction as "essentially territorial." Djokaba Lambi Longa v. the Netherlands, Application No. 33917/12, Decision, 9 October 2012, para. 69. Although the United Kingdom Defence Committee have questioned the presumption of territoriality in the application of the Convention, noting that "[m]ore recent cases, in particular Al-Skeini, have changed this position" - UK Armed Forces Personnel and the Legal Framework for Future Operations, supra note 117, para. 49.

204 Ukrainian Government, Resolution of the Verkhovna Rada, supra note 5. 
destroyed. ${ }^{205}$ In respect of Ukraine, the applicants complained that it was impossible to have several of their rights guaranteed because "all the State institutions in eastern Ukraine, including the courts, suspended their operations and were relocated to areas controlled by the Government of Ukraine."206 Similar conditions are also noted in the subsequent judgment of Khlebik v. Ukraine, where the applicant's appeal against a criminal conviction was delayed due to case files being located in an area which the Court noted was "not under the Ukrainian Government's control."2077 This factual profile, combined with the derogation that Ukraine has filed with the Court, contribute to the picture that Ukrainian authorities no longer exercise control over some areas in the east of the country. ${ }^{208}$

As noted in the previous section, when questions about whether a State exercises de facto control over its territory arise, it is unclear which approach the Court will take when determining whether the operative parts of the Convention will continue to apply. ${ }^{209}$ Applying Assanidze, the Court would conduct a detailed examination of the prevailing legal and factual elements. Importantly it would look to the fact that Ukraine had extended the Convention throughout its territory - subject to the derogations; that the regions of Donetsk and Luhansk clearly have some separatist aspirations, and that there could be an argument made that the regions were now subject to the effective overall control of another State. ${ }^{210}$ On the last point, while the actions of pro-Russian rebels would still require the test of attribution to be resolved, there is sufficient evidence to suggest that these armed groups have at least some control over the territory. The OHCHR reports on Ukraine have noted that " $t$ the selfproclaimed 'Donetsk people's republic' and self-proclaimed 'Luhansk people's republic' have undermined the human rights of the estimated 2.7 million people residing under

205 Lisnyy v. Ukraine and Russia, supra note 51, paras. 1-18.

206 Id. para. 19.

207 Khlebik v. Ukraine, Application No. 2945/16, Judgment (Section IV), 25 July 2017, para. 3.

208 The Court declared the application in Lisnyy and Others v. Ukraine inadmissible as the applicants had not sufficiently substantiated this case. Interestingly, the Court did so while recognising that the applicants would naturally have faced real practical difficulties in establishing their case given the conflict - Id. para. 29.

Article 15 (derogation in time of emergency) of the Convention allows for Contracting Parties to derogate, in a limited manner, from their obligation to secure some rights under the Convention. It should be noted that a number of core rights are non-derogable. The following provisions are nonderogable: the right to life, except in the context of lawful acts of war; the prohibition of torture and inhuman or degrading treatment or punishment; the prohibition of slavery and servitude; the rule of "no punishment without law"; Article 1 (abolishing the death penalty in peacetime) of Protocol No. 6; Article 1 (abolishing the death penalty in all circumstances) of Protocol No. 13 and Article 4 (the right not to be tried or punished twice) of Protocol No. 7 to the Convention. For a more comprehensive discussion on derogations within the ECHR framework see Bart van der Sloot, Is All Fair in Love and War? An Analysis of the Case Law on Article 15 ECHR, 53(2) Military Law and Law of War Review 319 (2014). 
their control" (emphasis added). ${ }^{211}$ The reports have reiterated the pro-Russian rebels' exercise of control on several occasions. ${ }^{212}$ Specifically it has been noted that there is an "absence of effective control of the Government of Ukraine over considerable parts of the border with the Russian Federation (in certain areas of Donetsk and Luhansk regions)."1213 By itself this could present a strong case that the Ukraine no longer exercises jurisdiction over some of the area, however, the question which arises is whether the ECtHR will follow this test from Assanidze or select a different path. As illustrated by Isayeva, where Russia had arguably lost control of areas of Chechnya, the Court is not always willing to engage with these issues. ${ }^{214}$

The contextual conditions in Chechnya during the Isayeva application bear striking similarities to the loss of control experienced by Ukraine in Donetsk and Luhansk. In both situations, the territorial State has resorted to armed force to displace an entrenched insurgency. It would be entirely possible for the ECtHR to follow the same approach it did in Isayeva and avoid conducting any inquiry into whether Ukraine has lost de facto control of parts of its territory, instead making a finding that Ukraine continued to owe Convention obligations within the conflict zones. This would, in turn, mean that Ukraine could be obliged to uphold positive obligations to investigate deaths, ${ }^{215}$ and positive obligations to protect the right to life of civilians within the relevant areas. ${ }^{216} \mathrm{It}$ is notable that neither of these obligations will be covered under the Ukrainian derogation.

If the Court were to conduct a detailed analysis and resolve that the Ukraine had lost its obligations in the areas under the de facto control of pro-Russian separatists, then the Court would most likely, in parallel, recognise Russia's exercise of jurisdiction within the relevant areas. As noted above in Sargsyan v. Azerbaijan, ${ }^{217}$ the Court is very reluctant to recognise the existence of a vacuum of human rights protection, where no Contracting Party exercises jurisdiction over an area which under normal circumstances would receive Convention protection.

211 OHCHR Report June 2016, supra note 9, at 7.

212 The Reports have noted that "the population living in the territories controlled by the armed groups has been effectively denied basic protection and deprived of basic human rights and freedoms." Id. In 2014 a report noted that "[c]urrently, armed groups remain in control of about 100 kilometers of the UkraineRussian Federation border" - Office of the United Nations High Commissioner for Human Rights, Report on the Human Rights Situation in Ukraine - 17 August 2014, 29 August 2014, at 5 (Aug. 2, 2018), available at http://www.ohchr.org/Documents/Countries/UA/UkraineReport28August2014.pdf.

213 Situation in Ukraine - 16 August to 15 November 2015, 9 December 2015, at 2 (Aug. 2, 2018), available
at http://www.ohchr.org/Documents/Countries/UA/12thOHCHRreportUkraine.pdf.

Isayeva v. Russia, supra note 21.

Id. para. 224.

Id. para. 201.

Sargsyan v. Azerbaijan, supra note 69. 


\subsection{Scenario 2 - Ukraine Owes Only Positive Obligations in Eastern Ukraine}

An alternative possibility would be that Ukraine's responsibility is limited to only positive obligations by virtue of its loss of de facto control over the areas in question. Such an approach would be akin to the ECtHR position in Ilaşcu and Catan, where Moldova's obligations were limited in Transdniestria. ${ }^{218}$ While this is perhaps the most likely interpretation that the ECtHR could arrive at, there remains a high-level of uncertainty over which positive obligations Ukraine would need to fulfil.

An example of where this question may arise relates to the downing of Malaysian Airlines Flight MH17. ${ }^{219}$ In July 2014, the commercial passenger airline was shot down over Eastern Ukraine killing all 283 passengers and 15 crew members. The mother of one of the German passengers has brought a case against Ukraine to the ECtHR for its failure to close the airspace above the conflict zone. ${ }^{220}$ Although it is largely accepted that the flight was shot down by pro-Russian rebels, Ukraine could still be held in violation of the positive obligation under Article 2 to protect life for failing to close its airspace. ${ }^{221}$ The question to be addressed would be whether this is one of the positive obligations which was applicable and what level of action would be required to fulfil the obligation. Following Ilaşcu, it is clear that a contracting State needs to make at least "a minimum effort" to protect individuals within de jure territory over which it has lost de facto control. ${ }^{222}$ This would suggest that the applicant could have some success before the Court, but, as explained above, only if Ukraine had been obligated to act through exercising its jurisdiction in the first place.

In sum, there is a distinct lack of clarity with regards to what obligations are owed by Ukraine in its Eastern territories. Ukraine may be responsible for all obligations which it has not derogated from in respect of Donetsk and Luhansk, only positive obligations in respect of these rights, or no obligations at all. The uncertainty means

218 Ilaşcu and Others v. Moldova and Russia, supra note 25 and Catan and Others v. Moldova and Russia, supra note 58.

219 For one perspective on Ukraine's human rights obligations in relation to this action see Daniela Copetti Cravo, Ukraine Liability for Violation of Human Rights in the Downing of Malaysian Airlines Flight MH17, 12 Brazilian Journal of International Law 728 (2015) (in Portuguese).

220 AFP, Mother of German MH17 Victim Takes Ukraine to Human Rights Court, The Telegraph, 30 November 2014 (Aug. 2, 2018), available at http://www.telegraph.co.uk/news/worldnews/europe/ukraine/11263486/ mother-of-german-mh17-victim-takes-ukraine-to-human-rights-court.html. The ECtHR confirmed it has received this communication in December 2014. The case, loppa v. Ukraine, Application No. 73776/14, has been given priority status. Ukraine: Flight MH17 Crash Victim's Mother Lodges Court Complaint, Human Rights Europe, 1 December 2014 (Aug. 2, 2018), available at http://www.humanrightseurope. org/2014/12/ukraine-flight-mh17-crash-victims-mother-lodges-court-complaint/.

221 AFP, Mother of German MH17 Victim Takes Ukraine to Human Rights Court, supra note 220. A Joint Investigation Team established in response to the attack recently stated that it "is convinced that the BUK-TELAR that was used to down MH17, originates from the $53^{\text {rd }}$ Anti Aircraft Missile brigade [...], a unit of the Russian army from Kursk in the Russian Federation" (Aug. 2, 2018), available at https:// www.om.nl/onderwerpen/mh17-crash/@103196/update-criminal-0/.

222 Ilaşcu and Others v. Moldova and Russia, supra note 25, para. 334. 
that the State is partially unaware, and thus able to plead ignorance, as to the range of rights it owes. Although the uncertainty affords the ECtHR with flexibility in interpreting particular levels of application to different factual circumstances, this approach sacrifices any meaningful legal certainty and thus States cannot adequately plan their actions with the awareness of what their precise obligations are. The uncertainty also means that individuals alleging breaches of the Convention will not be aware of which State owed them human rights obligations at the time of their injury. This unsatisfactory position, created by persistent ambiguity in the ECtHR's jurisprudence, means that at present it is not until many years later when the ECtHR rules on the applications that the State and individuals can fully appreciate what rights were owed and by whom.

\section{Russia's Responsibility for Human Rights}

Similar to Ukraine's responsibility for its volunteer battalions, a question arises as to whether the actions of pro-Russian rebels can be attributed to the Russian State. This issue turns on the extent to which the State instructs, directs or controls the armed group. ${ }^{223}$ Given the persistent denial by Russian representatives of any involvement, it may be difficult to prove that the rebels are either instructed or directed by Russian authorities. Depending on which interpretation is followed, ${ }_{1}^{224}$ there may also be difficulty in establishing the more flexible condition of control. ${ }^{225}$ Three different interpretations of how "control" is to be understood in this context have been advanced in the literature. The first is that for attribution to be found, the relevant State would need to have "had effective control" of the operations which gave rise to the alleged violation. ${ }^{226}$ This interpretation arose in the Nicaragua case where the ICJ held that although the United States was supporting a non-State armed group known as the contras, it was not in effective control of "all operations launched... at every stage of the conflict."227 This meant that any actions of the contras in breach of international human rights and international humanitarian law could not be attributed to the United States. ${ }^{228}$ Talmon notes that "unspecified

223 Crawford 2001, Art. 8.

224 Salmon notes that "[t]he test of control of authorities and military forces of secessionist entities has become perhaps the most cited example of 'the fragmentation of international law." Talmon 2009, at 496.

Gibney has noted that "the Russian-Ukrainian rebel relationship seems vastly weaker than that which existed between the United States and the Contras or that between Serbia and Bosnian Serb allies." Mark Gibney, The Downing of MH17: Russian Responsibility?, 15(1) Human Rights Law Review 169, 174 (2015).

Military and Paramilitary Activities in and against Nicaragua (Nicaragua v. United States of America), 1986 I.C.J. 54. This means that responsibility for conduct needs to be ascertained on a case by case basis.

227 Id. para. 106.

228 Id. 
claims of 'involvement' or 'direct participation' in certain of the secessionist entity's actions will not be enough to establish effective control over a particular activity or operation. ${ }^{\prime 229}$ The high threshold of attribution imposed by this test has been debated by commentators, ${ }^{230}$ and it has subsequently been followed by international courts, including the ICJ Bosnian Genocide judgment. ${ }^{231}$

A more flexible interpretation was provided by the Appeals Chamber of the International Criminal Tribunal for the Former Yugoslavia (hereinafter ICTY) in Tadić. ${ }^{232}$ Here the Court was not directly concerned with the issue of State responsibility. Instead it sought to establish whether Bosnian Serb units involved in the conflict were acting on behalf of the Serbia to internationalise a non-international armed conflict and thus bring with it culpability under Article 2 of the Fourth Geneva Convention. In coming to its decision, the Appeals Chamber noted that "[t]he degree of control may, however, vary according to the factual circumstances of each case. ${ }^{\prime \prime 233}$ The degree of control required "was overall control going beyond the mere financing and equipping of such forces and involving also participation in the planning and supervision of military operations."234 The Appeals Chamber found in the affirmative thus applying the ICTY Statute concerning "grave breaches" of the Geneva Convention.

On balance both the "effective control" and "overall control" tests set a relatively high standard for the attribution of conduct to a State for the actions of other persons or groups. Although Cassese correctly notes that the "overall control" test is more helpful in addressing "widespread trends in the practice of the world community,"235 it still may not be sufficiently flexible to allow for the attribution of responsibility for actions that have breached the ECHR in Ukraine. The Commentary on the Articles on State Responsibility notes that "[e]ach case will depend on its own facts, in particular those concerning the relationship between the instructions given or the direction

229 Law 649,653 (2007). Talmon notes that "it is still extremely difficult to establish the exercise of effective
control by the outside power over individual operations or activities of the secessionist entity." Talmon 2009, at 503. Application of the Convention on the Prevention and Punishment of the Crime of Genocide (Bosnia and
Herzegovina v Serbia and Montenegro), 2007 I.C. 143-47.

Id. para. 117.

Id. para. 145.

Cassese points specifically to the support State provide to military or paramilitary groups fighting abroad, the increase in State sponsored terrorism and the use of national military units as peacekeeping forces for international organisations. Cassese 2007, at 665-666. 
or control exercised and the specific conduct complained of." ${ }^{\prime \prime 36}$ Nonetheless, these particularly stringent tests generate significant difficulties in attributing conduct in the Ukrainian crisis, particularly concerning the actions of pro-Russian rebels.

Although clearly cognisant of the wider approach in international law, the ECtHR has not set as high a threshold in its attempts to establish responsibility for the conduct of individuals or groups affiliated with a State. The Court has instead sought to cultivate a test where attribution is found when the individuals or groups are under the "decisive influence" of a Contracting Party to the ECHR. ${ }^{237}$ This test emanated largely from the Ilaşcu litigation discussed earlier. ${ }^{238}$ In Ilaşcu the ECtHR found that Russia's "decisive influence" over Transdniestrian separatists in the breakaway MRT was sufficient to establish the responsibility of the Russian State for their conduct. Specifically, the Court noted that the MRT

remains under the effective authority, or at the very least under the decisive influence, of the Russian Federation, and in any event that it survives by virtue of the military, economic, financial and political support given to it by the Russian Federation. ${ }^{239}$

In the more recent judgment of Catan, also considered above, the Court reiterated the element of dependence in the relationship between the MRT and Russia noting that "the MRT's high level of dependency on Russian support provides a strong indication that Russia exercised effective control and decisive influence over the MRT administration."240 Moreover, the ECtHR again noted that the MRT existed "only because of Russian military, economic and political support."241 In Ivantoc, the Court further referred to Russia's connection as "a close relationship with the cause of Russian military, economic and political support.".242

236 Crawford 2001, at 48.

237 Talmon contends that the "overall control"and, as the ECtHR's "effective overall control" tests "broaden the scope of State responsibility well beyond the fundamental principle governing the law of international responsibility, which provides that a State is responsible only for its own conduct; that is to say the conduct of persons acting, on whatever basis, on its behalf." Talmon 2009, at 517. state actors can be imputed to a state when that state exercises decisive influence over the loca government." Koch 2016, at 183. Talmon refers to this test as one of "effective overall control" over territory of the secessionist entity, however he distinguishes it from the "effective control" test used by the ICJ instead noting that: "[t]he effective overall control of the outside power is used as a basis for equating the authorities of the secessionist entity with de facto State organs or 'agents' of the outside power for whose acts it may generally be held responsible."Talmon 2009, at 509-510.

See supra Section 2.

Ilaşcu and Others v. Moldova and Russia, supra note 25, para. 392.

Catan and Others v. Moldova and Russia, supra note 58, para. 122.

Ivantoc and Others v. Moldova and Russia, supra note 153, para. 118. 
By applying these standards to the situation in Eastern Ukraine a case can be made that pro-Russian rebels are, at the very least, under the "decisive influence" of the Russian Federation. ${ }^{243}$ This argument would primarily be grounded in the military support that the rebels appear to be receiving from the Russian Federation. In late 2014, NATO released satellite imagery which purported to show "Russian combat forces engaged in military operations inside the sovereign territory of Ukraine."244 Senior NATO official Brigadier General Tak commented that NATO had "detected large quantities of advanced weapons, including air defence systems, artillery, tanks, and armoured personnel carriers being transferred to separatist forces in Eastern Ukraine."245 NATO Commander Philip Breedlove further stated that the assistance being provided by the Russian State to the rebels is offered in a variety of ways noting that "[f]orces, money, support, supplies, weapons are flowing back and forth across this border completely at will."246

The OSCE deployed a Special Monitoring Mission to Ukraine in March 2014. ${ }^{247}$ At one point that year, the mission reported the sighting of "540 men and women in military-style dress" crossing the border in both directions. ${ }^{248}$ By June 2016, the mission had reported 52 border crossing convoys between Russia and Ukraine. ${ }^{249}$ This is further supported by the OHCHR Special Mission to Ukraine which has noted that

The argument that they are acting under Russian direction, instructions or control may be more difficult to substantiate. Reeves and Wallace argue with regard to Russian involvement that "it is difficult to determine the full extent and scope of their control of the separatists, as the Russianbacked rebels are seemingly independent actors." Reeves \& Wallace 2015, at 382.

244 North Atlantic Treaty Organization, NATO Releases Satellite Imagery Showing Russian Combat Troops Inside Ukraine, 26 November 2014 (Aug. 2, 2018), available at http://www.nato.int/cps/en/natohq/ news_112193.htm. In discussing Russia's approach, Remler notes that the Russian approach has been characterized as "hybrid warfare," noting that "Russia's campaign in Ukraine is characterized inter alia by deniable (or at any rate denied) military support for pro-Russian forces of 'activists', including the (denied) deployment of combat troops among the local 'activists', all aimed at disguising invasive warfare as civil unrest and civil war." Philip Remler, Ukraine, Protracted Conflicts and the OSCE, 26(1) Security and Human Rights 88, 92 (2015).

245 He has further commented that "Russia is reinforcing and resupplying separatist forces in a blatant attempt to change the momentum of the fighting, which is currently favouring the Ukrainian military." NATO Releases Satellite Imagery Showing Russian Combat Troops Inside Ukraine, supra note 244.

Ewen MacAskill, Russian Tanks and Troops Crossing into Ukraine, Says Nato Commander, The Guardian, 12 November 2014 (Aug. 2, 2018), available at https://www.theguardian.com/world/2014/nov/12/ russian-tanks-troops-crossing-into-ukraine-nato-supreme-commander. Organization for Security and Co-operation in Europe, Permanent Council Decision No. 1117, 21 March 2014 (Aug. 2, 2018), available at http://www.osce.org/pc/116747.

Organization for Security and Co-operation in Europe, Weekly Update from the OSCE Observer Mission at Russian Checkpoints Gukovo and Donetsk Based on Information as of 08:00 (Moscow time), 22 October 2014 (Aug. 2, 2018), available at http://www.osce.org/om/125776.

Organization for Security and Co-operation in Europe, Spot Report by OSCE Observer Mission at Russian Checkpoints of Gukovo and Donetsk: Fifty-Second Russian Convoy of 45 Vehicles Crossed into Ukraine and Returned Through Donetsk Border Crossing Point, 23 June 2016 (Aug. 2, 2018), available at http://www.osce.org/om/248341. 
[c]redible reports indicate a continuing flow of heavy weaponry and foreign fighters throughout the reporting period, including from the Russian Federation, into areas of the Donetsk and Luhansk regions controlled by armed groups. This has sustained and enhanced the capacity of armed groups of the self-proclaimed "Donetsk People's Republic" and "Luhansk People's Republic" to resist Government armed forces and to launch new offensives in some areas, including around the Donetsk airport, Mariupol and Debaltseve. ${ }^{250}$

Specifically the Report notes that

[r]epresentatives of the "Donetsk People's Republic" have recognised the presence within their armed groups of citizens of the Russian Federation, including from Chechnya and other republics of the North Caucasus. ${ }^{251}$

These military contributions, in the form of personnel and equipment, made by the Russian Federation to pro-Russian rebels in Luhansk and Donetsk present a strong case that the groups are under the "decisive influence" of the Russian State for their actions to be attributable to it in litigation brought to the ECtHR. With attribution therefore possible, there are two possible scenarios under which Russia will be held to exercise jurisdiction.

\subsection{Scenario 1 - Russia Exercises Spatial Jurisdiction over Eastern Ukraine}

As well as establishing a case for attribution, the preceding section has identified many of the characteristics which are considered in the test of "spatial jurisdiction."252 In February 2018, Ukrainian authorities launched a new public policy which recognised that the areas in Donetsk and Luhansk not under Ukrainian control were subject to

250 Office of the United Nations High Commissioner for Human Rights, Report on the Human Rights Situation in Ukraine - 1 December 2014 to 15 February 2015, 15 February 2015, at 3 (Feb. 15, 2015) (Aug. 2, 2018), available at http://www.ohchr.org/Documents/Countries/UA/9thOHCHRreportUkraine.pdf.

251 Office of the United Nations High Commissioner for Human Rights, Report on the Human Rights Situation in Ukraine - 15 June 2014, 15 June 2014, at 3 (Aug. 2, 2018), available at http://www.ohchr. org/Documents/Countries/UA/HRMMUReport15June2014.pdf. The report further notes at 4:"There are credible reports from different sources, including the OSCE Observer Mission, that hundreds of people in military-style clothing have been observed crossing the two border crossing points of Gukovo and Donetsk in both directions. The Ukrainian Government and some civic groups report the delivery of weapons from the Russian Federation to the eastern regions. On 19 September and 31 October, two further convoys were sent by the Russian Federation to territory under the control of the 'Donetsk people's republic' and 'Luhansk people's republic.' As on the previous occasions, the convoys crossed at the Izvaryne border crossing point without the authorisation of Ukraine, and were not inspected."

Talmon has noted how the ECtHR consideration on the issues of attribution and spatial control frequently overlap: "These two questions, however, are not always clearly kept apart as the Court seizes on the element of 'control' to establish both extraterritorial 'jurisdiction' and imputability and seems to derive the one from the other."Talmon 2009, at 508. 
temporary occupation by Russia. ${ }^{253}$ The statements by the OHCHR further indicate that Russian supported rebels exercise a high degree of control over the territories of Luhansk and Donetsk. The reports by the OSCE and NATO demonstrate that the separatist regions are somewhat reliant on Russian military support to exist. In previous cases before the ECtHR, there has been a tendency for the Court to recognise that support for a subordinate administration and control over territory are sufficient for a dual-finding of attribution and spatial jurisdiction. In relation to the Turkish support for the TRNC in the above-mentioned Loizidou case, the Court noted that

[i]t is not necessary to determine whether a Contracting Party actually exercises detailed control over the policies and actions of the authorities in the area situated outside its national territory, since even overall control of the area may engage the responsibility of the Contracting Party concerned. ${ }^{254}$

Later, the Court would reiterate this position in a further inter-state case between Cyprus and Turkey

Having effective overall control over Northern Cyprus, its responsibility cannot be confined to the acts of its own soldiers or officials in Northern Cyprus but must also be engaged by virtue of the acts of the local administration which survives by virtue of Turkish military and other support. ${ }^{255}$

With this being the case, there is a concurrent argument to be made that through its military support of pro-Russian rebels, the Russian Federation exercises effective control of the relevant area and is responsible for any violations of the Convention committed within those areas. ${ }^{256}$ As mentioned in the preceding section, a finding that Russia exercises spatial jurisdiction over the areas controlled by rebels may open the gateway for the Court to absolve Ukraine of some Convention responsibilities within these areas. ${ }^{257}$

While a finding that Russia exercised spatial jurisdiction over Donetsk and Luhansk would simplify some of the questions around who must guarantee human rights protection within Eastern Ukraine, there are several compelling reasons to suspect

253 Report on the Human Rights Situation in Ukraine - 16 November 2017 to 15 February 2018, supra note 12 , at 28. crisis in Ukraine has produced an enlarged group of unrecognized separatist polities in communion with one another." Remler 2015, at 93. with one another." Remler 2015, at 93.

See supra Section 2. 
that the ECtHR may not take such an approach. Firstly, the Court tends to avoid finding spatial jurisdiction during live conflicts. As discussed in the first section, the Court failed to even test for spatial jurisdiction in Iraq, both during the phase of active hostilities in Hassan, ${ }^{258}$ and while the United Kingdom was in belligerent occupation of the South-East of the country in Al-Skeini. ${ }^{259}$ Instead, the Court has appeared much more willing to find spatial jurisdiction in entrenched conflicts, when States have assumed control over regions for a prolonged period of time as illustrated in the Court's jurisprudence arising from Northern Cyprus and Transdniestria. ${ }^{260}$

As an extension of this, a second reason why the ECtHR may be unlikely to find spatial jurisdiction is because of the practical implications this finding would have on other applications. If the Court concludes Russia is exercising spatial jurisdiction in one case, it will open Russia to liability for all violations of the Convention within that region. Judges at the Court have been reluctant to "open the floodgates" in this way in previous cases. In Loizidou, for instance, Judge Bernhardt's separate opinion warned that the impact of the judgment would not be restricted to the applicant. Instead it would also concern the "thousands or hundreds of thousands of Greek Cypriots who have (or had) property in Northern Cyprus."261 The same would follow from a finding that Russia exercises spatial jurisdiction in Eastern Ukraine. The complication of having to fulfil all rights and responsibilities under the Convention when spatial jurisdiction is exercised has been discussed earlier. ${ }^{262}$

A third reason why the ECtHR may not find that Russia is exercising "spatial jurisdiction" in Eastern Ukraine is how politically charged such a decision would be. Recognising that Russia was in control of Eastern Ukraine would be highly controversial and, although judgments should not be influenced by the potential responses of contracting States, it would almost certainly result in a backlash against the Court, ${ }^{263}$ and may even affect any peace talks aimed at finding a political settlement to the dispute. ${ }^{264}$ Referring again to the Loizidou judgment, White commented at the

258

Hassan v. United Kingdom, supra note 14.

Al-Skeini and Others v. United Kingdom, supra note 18.

Loizidou v. Turkey (Merits), supra note 254; Cyprus v. Turkey, supra note 35; Ilaşcu and Others v. Moldova and Russia, supra note 25; Catan and Others v. Moldova and Russia, supra note 58.

Loizidou v. Turkey (Merits), supra note 254 (Separate Opinion of Judge Bernhardt), para. 1.

See supra Section 2.2.2 "Is Upholding All Convention Rights in Crimea Feasible?"

The Russian Federation has a particularly tense relationship with the Court. This is explored below in the Observations section. See also Courtney Hillebrecht, The Rocky Relationship Between Russia and the European Court of Human Rights, Washington Post, 23 April 2014 (Aug. 2, 2018), available at https://www.washingtonpost.com/news/monkey-cage/wp/2014/04/23/the-rocky-relationshipbetween-russia-and-the-european-court-of-human-rights/.

This was a further concern raised by Judge Jambrek in his dissenting opinion on the Loizidou merits. "Given that efforts are under way to arrive at a peaceful settlement of the Cyprus problem within UN, CE and other international bodies, a judgment of the European Court may appear as prejudicial." Loizidou v. Turkey (Merits), supra note 254 (Separate Opinion Judge Jambrek), para. 7. 
time that the finding was either very courageous, given the political context the ECtHR faced, or very unwise given the on-going nature of the dispute which was embedded in both historical and political disagreements. ${ }^{265}$

Rather than finding spatial jurisdiction, it is more likely that the ECtHR will determine that pro-Russian rebels exercise personal jurisdiction over the individuals in Eastern Ukraine. That approach, however, is also not free from difficulty.

\subsection{Scenario 2 - Russia Exercises Personal Jurisdiction over Individuals Within Eastern Ukraine}

Personal jurisdiction, like spatial, is most commonly dependent on the exercise of de facto control - this time by a State agent over an individual as opposed to an area. The ECtHR's lack of consistency in ascertaining de facto control is clear with regard to personal jurisdiction. Before discussing this approach, it is important to remember the critical distinction in the obligations owed by the State in exercising personal rather than spatial jurisdiction under the ECHR. While a State which exercises spatial jurisdiction is obligated to fulfil all the rights within the Convention, personal jurisdiction only requires the State to secure rights that are "relevant to the situation of that individual.".266 The Court has commented that "[i]n this sense, therefore, the Convention rights can be 'divided and tailored."'1267 How this is to be interpreted is wholly unclear. As Miltner notes, the Court can now possibly "cherry pick" which rights are applicable in a given situation. ${ }^{268}$ This approach further suggests that the rights can be internally tailored so that some of the obligations within the rights will not need to be fulfilled. For instance, this may mean that a State only needs to fulfil the procedural components of the right to life, but not the substantive negative restrictions on taking life, or vice versa. ${ }^{269}$ The obscurity of this again leaves States with little guidance as to which rights and duties they owe when overseas.

Beyond this initial ambiguity, this section offers analysis of three competing interpretations of how de facto control over individuals gives rise to personal jurisdiction, and how these interpretations may be applied in the context of violations committed by pro-Russian rebels during the conflict in Eastern Ukraine. As with spatial jurisdiction, these approaches are rife with internal contradictions and are

265 Robin C.A. White, Tackling Political Disputes Through Individual Applications, 1 European Human Rights Law Review 61, 71 (1998).

Al-Skeini and Others v. United Kingdom, supra note 18, para. 137.

Id.

Miltner 2012, at 697.

Bearing in mind that in Al-Skeini the Court was not posed with the question of whether the right to life had been breached in the shooting of unarmed civilians, rather instead whether the right had been breached due to the failure to set-up an independent and effective investigation into the deaths. Al-Skeini and Others v. United Kingdom, supra note 18. 
often incompatible with one another. The result is a lack of clarity concerning when and where the Convention applies.

\subsubsection{Pro-Russian Rebels Exercise Direct Control over Individuals Through Custody}

The first of these approaches suggests that de facto control will only give rise to a jurisdictional link where the victim has been brought within the custody of a State agent. There have been numerous reports of individuals being abducted, captured and detained against their will by pro-Russian rebels in Eastern Ukraine. ${ }^{270}$ One example is the capture of Nadiya Savchenko, a servicewoman in the Ukrainian Air Force, by proRussian separatists in Luhansk. ${ }^{271}$ She has applied to the ECtHR alleging breaches of Article 5, the right to liberty and security, and Article 6, the right to a fair trial within a reasonable time. ${ }^{272} \mathrm{~A}$ preliminary question that may arise in this case is whether Russia exercised jurisdiction over Ms Savchenko when she was captured in Ukraine, before she was transferred to the Voronezh region of the Russian Federation. ${ }^{273}$

The extent to which physical custody equates to control was addressed by the ECtHR in Al-Skeini where it was stated that

the Court's case law demonstrates that, in certain circumstances, the use of force by a state's agents operating outside its territory may bring the individual thereby brought under the control of the state's authorities into the State's Art. 1 jurisdiction. This principle has been applied where an individual is taken into the custody of state agents abroad. ${ }^{274}$

A critical deconstruction of this passage is necessary to understand the ECtHR's approach. Although the core of the message here is clear, that jurisdiction arises through de facto control when an individual is within the custody of State agents, the statement is riddled with inconsistencies and potential qualifications. First, the ECtHR's reference to the "use of force" is ambiguous. Typically, the term is used to

OHCHR Report June 2016, supra note 9, at 13-17. Amnesty International, Ukraine: Overwhelming New Evidence of Prisoners Being Tortured and Killed Amid Conflict, 25 May 2015 (Aug. 2, 2018), available at https://www.amnesty.org/en/latest/news/2015/05/ukraine-new-evidence-prisoners-tortured-andkilled-amid-conflict/; Lily Hyde, Lost Souls from the Ukrainian War, Foreign Policy, 30 March 2016 (Aug. 2, 2018), available at http://foreignpolicy.com/2016/03/30/lost-souls-from-the-ukrainian-war-russiaprisoners-detainees-exchanges/; International Committee of the Red Cross, Ukraine: ICRC Facilitates Release and Transfer of Conflict-Related Detainees, 29 October 2015 (Aug. 2, 2018), available at https:// www.icrc.org/en/document/ukraine-icrc-facilitates-release-and-transfer-conflict-related-detainees. Savchenko v. Russia, Application No. 50171/14 (Aug. 2, 2018), available at http://hudoc.echr.coe.int/app/ conversion/pdf/?library=ECHR\&id=003-5014897-6157176\&filename=003-5014897-6157176. pdf. OHCHR Report June 2016, supra note 9, at 22. 
describe the resort to military force by States, ${ }^{275}$ or the use of lethal and other forms of force by State agents in a human rights context. ${ }^{276}$ In this quote, the ECtHR uses it to describe custody and detention, which gives rise to questions over whether the ECtHR is implicitly excluding the use of deadly force from this basis of jurisdiction? This ambiguity is considered further below.

Second, the ECtHR notes that jurisdiction does not arise in every instance involving "the use of force," but only "in certain circumstances" and the use of force "may bring" an individual into Article 1 jurisdiction. The level of conditionality here is palpable and it leaves the ECtHR with a large amount of flexibility to extend jurisdiction on an ad hoc basis. A third notable feature of the statement is the incomprehensible language of the clause's dominant sentence, specifically the phrase "bring an individual thereby brought under the control of the state's authorities."277 This wording suggests that the use of force may not bring an individual within the State's jurisdiction unless that individual is thereby brought under control. Thus, it is not clear exactly when jurisdiction would arise. This ambiguity falls at the precise moment when clarity is most needed. ${ }^{278}$

The uncertainty is only resolved when one looks further at the cases the ECtHR has used to justify this position. ${ }^{279}$ The Court notes that the rule has been applied where an individual is taken into the custody of agents abroad and cites four cases to support this proposition that custody equates to de facto control, however when the facts of those cases are examined some key differences emerge. For instance, the Court in Al-Skeini noted that jurisdiction arose in the case of Öcalan v. Turkey, because the Kurdish rebel leader, Abdullah Öcalan, was arrested at Nairobi International Airport in Kenya before being boarded onto a Turkish aircraft and forcibly returned to Turkish territory. ${ }^{280}$ In Al-Saadoon and Mufdhi, the applicants, who were suspected of killing a British soldier, were arrested and taken into UK custody at a military

275 Charter of the United Nations, Art. 2(4); Declaration on Principles of International Law Concerning Friendly Relations and Cooperation Among States in Accordance with the Charter of the United Nations.

276 Convention for the Protection of Human Rights and Fundamental Freedoms, Art. 2(1).

277 Al-Skeini and Others v. United Kingdom, supra note 18, para. 136.

278 This ambiguous statement has since been interpreted by the Inter-American Commission on Human Rights in Ameziane v. United States, where an individual had been apprehended in Pakistan and detained in various US military facilities. The Inter-American Commission on Human Rights implied that the instantaneous act of apprehending him was of itself decisive in creating the jurisdictional link and cited the aforementioned paragraph in Al-Skeini as authority. The Commission referred to the "exercise of physical power and control over the person in question" as "the decisive element" in finding jurisdiction. Ameziane v. United States, IACHR Report No. 17/12, Petition P-900-08, Admissibility (20 March 2012), para. 31. 
detention facility in Iraq. ${ }^{281}$ In Medvedyev, French commandos took control of a ship and its crew in international waters. The ECtHR held that French authorities had "exercised full and exclusive control over the [ship] and its crew" from the point of interception until the ship's arrival in a French port. ${ }^{282}$ Finally, in Issa, it was alleged that Turkish soldiers had taken a group of shepherds into their custody in Northern Iraq, brought them to a nearby cave and executed them. Although the ECtHR ruled there was insufficient evidence to establish a jurisdictional link to the soldiers, had the facts been accepted, the deceased would have been within Turkish jurisdiction by virtue of the soldiers' authority and control over them. ${ }^{283}$

By stating that these cases underpin the idea that de facto control equates to custody, the ECtHR is presenting a retrospective reinterpretation of its own rulings. In Al-Saadoon, for example, the ECtHR held that jurisdiction arose because the UK was exercising control "over premises" within which the applicants were located, i.e. the detention facility, and not individual persons. ${ }^{284}$ Similarly, in Medvedyev the jurisdictional link appears to arise from the de facto control that French commandos exercised over the applicants' vessel, and not the applicants themselves. ${ }^{285}$ The selective re-evaluation is most evident with the Issa case. When the Grand Chamber considered the facts of this case in Al-Skeini, it read the case to mean that if it had been established that the victims were taken into custody, brought to a nearby cave and then executed, jurisdiction would have been established. Yet there is no mention of this approach whatsoever in Issa. Instead the ECtHR had considered whether Turkey could have been exercising spatial jurisdiction on a temporary basis, stating that "in the case under consideration what is crucial is whether the Turkish troops exercised effective control over the area where the killings took place." ${ }^{286}$ Indeed, of the four cases that the Court relies on to establish this rule, only Öcalan is followed without being subjectively reinterpreted.

Notwithstanding the awkward syntax deployed and the questionable interpretation of previous jurisprudence, there is a strong suggestion that the Court in Al-Skeini was attempting to establish that de facto control only gives rise to jurisdiction when an individual is brought within a State agent's custody. In Savchenko's case then, she would have fallen within Russian jurisdiction for the purposes of Article 1 from the moment that she was captured and brought under the rebel group's physical control.

\footnotetext{
281 Al-Saadoon and Mufdhi v. United Kingdom, supra note 124.

282 Medvedyev v. France, supra note 113, para. 67.

283 Issa and Others v. Turkey, supra note 87.

284 Al-Saadoon and Mufdhi v. United Kingdom, supra note 124, para. 88.

285 Medvedyev v. France, supra note 113, para. 67.

286 Issa and Others v. Turkey, supra note 87, paras. 74-76.
} 


\subsubsection{Pro-Russian Rebels Exercise Control over Individuals Due to Their Location}

Despite this purported focus on the exercise of de facto control over individuals, the Court has also developed an approach which looks to the control a State exercises over spaces and locations rather than people. ${ }^{287}$ This interpretation is again illustrative of the ECtHR's inconsistent attitude to the meaning of de facto control in personal jurisdiction.

This approach will be relevant to the hundreds of cases involving soldiers and civilians who have been detained on either side of the conflict. ${ }^{288}$ One OHCHR report on the Human Rights Situation in Ukraine gives the account of a Ukrainian serviceman who was captured in August 2015 by four members from a battalion of the "Donetsk People's Republic.".289 The serviceman was taken to a private house where he was beaten, threatened and tortured with electric shocks for a number of hours. Eventually he was transported to a military base in the centre of Makiivka. ${ }^{290}$ The question which arises from these facts is when did the serviceman fall within Russian jurisdiction and at what point did Russia become responsible for guaranteeing the protection of his human rights?

Following the above approach of physical custody equating to de facto control and thus jurisdiction, the serviceman would have fallen into Russian jurisdiction from the moment of his capture. The ECtHR, however, has not always remained loyal to that position, instead leaning towards an approach where jurisdiction arises because of the control exercised over a location. The term "location" in this sense covers a multitude of small spatial areas including fixed premises like military facilities and prisons, vehicles and checkpoints. The distinctive characteristic is that the test looks at the location primarily, rather than the person.

Given the general difficulties inherent in establishing clear lines of responsibility here, there is an obvious attraction toward such an approach. After all, locations are generally much easier to secure control over as they can be fortified, defended and a degree of permanence can be established over them. The problem is that such an interpretation is simply unworkable in a human rights framework as it fundamentally distinguishes between beneficiaries of human rights, and those who lie outside human rights protection, on the basis of inches and feet. ${ }^{291}$ Clearly a State will have

287 The terminology of the UK Courts in labelling this basis was to term it as "quasi-territorial" jurisdiction Rix J, R (on the application of Al-Skeini and Others) v. Secretary of State for Defence (the Redress Trust intervening) [2004] E.W.H.C. 2911 (Admin), para. 270.

Russian Soldiers Detained in Ukraine Face Life Imprisonment - Lawyer, Ukraine Today, 26 August 2015 (Aug. 2, 2018), available at http://uatoday.tv/politics/russian-soldiers-detained-in-ukraine-facelife-imprisonment-lawyer-482047.html. 
better control over a fortified military outpost, or prison, than they do on the streets while deployed abroad. Nonetheless, there is a compelling argument to say that, as in the example given, the level of control exercised over an individual is equal whether they are captured and brought to a military facility and tortured or captured and taken to a remote location off base where they are also tortured.

In the example given, the question would be whether sufficient control was exercised over the private house where the serviceman was tortured to trigger his Convention rights. If the answer is no, then on the basis of this location-based approach he would not have been owed any obligations until he arrived at the military base. The ECtHR in Al-Skeini recognised the unsustainability of this approach and elected to establish a test of de facto control over the person stating that it

does not consider that jurisdiction in the above cases arose solely from the control exercised by the contracting state over the buildings, aircraft or ship in which the individuals were held. What is decisive in such cases is the exercise of physical power and control over the person in question. ${ }^{292}$

Here the Court has strained to clarify that custody through the exercise of de facto control refers specifically to the exercise of power and control over the individual and not a place. Milanovic notes that the inclusion of the word "solely" here will leave the door open for future wider interpretations on a spatial basis and, as will be demonstrated, this is exactly what the Court has done subsequently. ${ }^{293}$

Despite taking these steps to clarify that personal jurisdiction arises through de facto control when an individual is taken into custody, the ECtHR almost immediately turned to the notion that personal jurisdiction held some form of spatial quality. ${ }^{29} \mathrm{On}$ the same day that the Al-Skeini judgment was delivered, a Grand Chamber composed of exactly the same judges handed down the Al-Jedda judgment..$^{295}$ This application concerned a violation of the right to liberty of an Iraqi civilian interned by British forces in Southern Iraq. ${ }^{296}$ The Court held that the individual was within UK jurisdiction because he was "within a detention facility in Basra City, controlled exclusively by British forces." ${ }^{129}$ In this case, the Court derived a jurisdictional link from control over the facility, not from the physical control exercised over the individual. It was

292

Al-Skeini and Others v. United Kingdom, supra note 18, para. 136.

Milanovic 2012, at 128.

This approach was consistent with the Court's ultimate finding of jurisdiction in Al-Skeini which, although purportedly being based on personal principles, held a spatial element in relation to the exercise of public powers.

Al-Jedda v. United Kingdom, supra note 125.

Id. paras. 9-15.

Id. para. 85 . 
also determinative that the control exercised was exclusive. Presumably the Court intended for it to be consequential that complete control over a facility resulted in direct control over a person, yet the lack of consistency is obvious.

The case of Hirsi Jamaa v. Italy is another such example. ${ }^{298}$ This application concerned the interception and "push back" of a migrant vessel at sea by the Italian coastguard. The applicants had been taken from their skiff and placed on an Italian coastguard vessel before being returned to Libya. They alleged that their return violated the non-refoulement obligations in Article 3's prohibition on torture, inhuman and degrading treatment or punishment. When examining whether the applicants fell within Italian jurisdiction while aboard the Italian vessel, the Court, citing Al-Skeini, referred to the need for "full and exclusive control over a prison or a ship" to give rise to a jurisdictional link. ${ }^{299}$ The Court in Al-Skeini had not specifically referred to the need for control over place or vehicle at all, in fact, as illustrated above, it stated quite the opposite. ${ }^{300}$

The ECtHR returned to the idea that control equates to the exercise of physical power over the individual in custody. In Hassan v. United Kingdom, mentioned above, the Court noted that

[f]ollowing his capture by British troops early in the morning of 23 April 2003, until he was admitted to Camp Bucca later that afternoon, Tarek Hassan was within the physical power and control of the United Kingdom soldiers and therefore fell within United Kingdom jurisdiction. ${ }^{301}$

This brings the discussion back full circle to the position where jurisdiction through force can be found, but only when direct physical control is exercised over an individual in custody.

In the case of Jaloud, the Court appeared to stretch this location-based approach to de facto control even further. Jaloud concerned the death of an Iraqi civilian who was killed when Iraqi and Dutch soldiers fired upon his car as it approached a checkpoint in April 2004. ${ }^{302}$ The Court found jurisdiction on the basis that the Dutch forces exercised "authority and control over persons passing through the checkpoint.".303 Thus, the de facto control being exercised was primarily over a checkpoint rather

298

Hirsi Jamaa v. Italy, supra note 28.

Id. para. 73.

Al-Skeini and Others v. United Kingdom, supra note 18, para. 136.

Hassan v. United Kingdom, supra note 14, para. 76.

The applicants in this case argue that the firing of a bullet is a result of the authority and control which the Dutch forces in Iraq exercised over the victim at the relevant time. It was unclear whether the bullets which killed him were fired by the Iraqi or Dutch forces.

Jaloud v. Netherlands, supra note 36, para. 152. 
than the individuals in transit through the location. ${ }^{304}$ Aurel Sari suggests that the Court's approach in Jaloud was to make a finding of jurisdiction for any individual within a Contracting Party's "sphere of control." ${ }^{305}$ He notes that this flexibility "may stretch the extra-territorial applicability of the ECHR to its breaking point."

Focusing specifically on the Ukrainian serviceman who was tortured off-base, there remains a degree of uncertainty as to how he would fall within Russian jurisdiction. Although jurisdiction is likely to be found based on the control exercised over him directly on capture, it may alternatively be found due to the control exercised over either the private house or military facility. Thus, a potential grey area arises between when he was captured and taken to the private house, which States may seek to exploit by arguing that they did not appreciate their obligations would extend in such circumstances.

\subsubsection{Pro-Russian Rebels Exercise Control Through Instantaneous Acts}

The ECtHR has traditionally refused to recognise that jurisdiction can arise from instantaneous acts, i.e. that an individual falls within the jurisdiction of a State simply by virtue of having suffered a human rights violation at the hands of that State's agents. That approach was established in the, now much maligned, Banković case. ${ }^{307}$ In this admissibility application, the ECtHR held that individuals who had been injured or killed in a NATO airstrike on a radio/TV station in Belgrade in 1999 fell outside the Respondent States'jurisdiction for the purposes of Article 1. This is because the Federal Republic of Yugoslavia was not a Contracting Party to the treaty and the Convention only applied to European "legal space," i.e. the territory of signatory States. ${ }^{308}$ Thus no jurisdictional link could be found between the victims and the State forces that had

304 A similar finding was made in the more recent Pisari case where Russia was found to exercise jurisdiction over a check-point in Moldova. The Court noted that Russia had exercised jurisdiction as the checkpoint was "manned and commanded by Russian soldiers" - Pisari v. Moldova and Russia, Application No. 42139/12, Decision (Section III), 21 April 2015, para. 33.

305 Sari notes that "Jaloud suggest that a Contracting Party's jurisdiction may be engaged when it deploys military assets to contribute to security and stability in a third country and brings individuals within its sphere of control, even without exercising direct control either over those individuals or their geographical surroundings." Aurel Sari, Untangling Extra-Territorial Jurisdiction from International Responsibility in Jaloud v. Netherlands: Old Problem, New Solutions?, 53 Military Law and the Law of War Review 287, 301 (2014). Id. at 314 .

307 Banković and Others v. Belgium and Others, supra note 28. This case has been the subject of extensive academic critique. See, for instance, O'Boyle 2004, at 130; Joanne Williams, Al Skeini: A Flawed Interpretation of Banković, 23(4) Wisconsin International Law Journal 687 (2005); Stefka Kavaldjieva, Jurisdiction of the European Court of Human Rights: Exorbitance in Reverse?, 37(3) Georgetown Journal of International Law 507 (2006); Kerem Altiparmak, Banković: An Obstacle to the Application of the European Convention on Human Rights in Iraq?, 9(2) Journal of Conflict and Security Law 213 (2004). 
conducted the attack. ${ }^{309}$ The Court expressly took the position in this case that a "cause and effect" approach to jurisdiction in Article 1 of the Convention was unsustainable. ${ }^{310}$ This decision was followed in Medvedyev where the Court referred to instantaneous acts equating to jurisdiction as an "excluded situation."311

While some have argued that a cause and effect approach would be illogical, ${ }^{312}$ the alternative runs into considerable normative difficulties when addressing cases which involve the use of force against individuals. As the argument goes, whether the State kills a person with a missile or after they are detained, it is still exercising ultimate power and control over them. Drawing distinctions between such situations based on whether an individual is within physical custody or not would be arbitrary and, as expressed by Schaefer, "arguably morally grotesque.."133 One former ECtHR judge has described the distinction as creating a "ludicrous result.".114 Moreover, to avoid a jurisdictional link, the distinction creates a perverse incentive for States to shoot people, rather than attempting to capture and arrest them. ${ }^{315}$

In the Ukrainian context, there have been numerous instances where individuals have been killed or injured when outside the custody of rebel groups and away from a location controlled by those forces. The targeting of MH17 is perhaps the most profound example of this. In addition to the German mother who has brought a claim against Ukraine to the ECtHR following the death of her child in the incident, the families of a group of Australians killed on board the flight have also alleged that Russia violated the right to life of their family members before the ECtHR as it was Russian-backed separatists who are alleged to have launched the missile which

This case can be directly contrasted with the "Brothers to the Rescue case" at the Inter-American Commission on Human Rights. Cuban military aircraft intercepted a civilian aircraft in international airspace and shot it down. When assessing jurisdiction, the Commission relied on a form of personal jurisdiction finding that the act of firing on the aircraft amounted to an exercise of authority over it: "the victims died as a consequence of direct actions taken by agents of the Cuban State in international airspace [...] The Commission finds conclusive evidence that agents of the Cuban State, although outside their territory, placed the [civilian pilots] under their authority." Armando Alejandre Jr., Carlos Costa, Mario de la Peña, and Pablo Morales v. Cuba, Report No. 86/99, Case 11.589 (29 September 1999), para. 25.

Banković and Others v. Belgium and Others, supra note 28, para. 73.

311 Medvedyev v. France, supra note 113, para. 64.

312 Lea Raible makes a case against the cause and effect approach noting that "saying that one can create obligations under the Convention by violating them is simply absurd." Raible 2016, at 161.

313 Max Schaefer, Al-Skeini and the Elusive Parameters of Extraterritorial Jurisdiction, 5 European Human Rights Law Review 566, 575 (2011); Milanovic 2012, at 129.

Loukis Loucaides, Determining the Extra-Territorial Effect of the European Convention:Facts, Jurisprudence and the Bankovic Case, 4 European Human Rights Law Review 391, 400 (2006). 
brought the aircraft down. ${ }^{316}$ If Russia is not considered to exercise spatial jurisdiction over the area in Eastern Ukraine where the airplane was targeted, then the families would need to demonstrate that Russia exercised personal jurisdiction over the individuals within the aircraft at the relevant time. ${ }^{317}$

In the years since the Banković case, the Court has found jurisdiction through de facto control on what can be described as an instantaneous basis on several occasions. The way the Court has done so, however, has only layered the confusion over what actions will give rise to jurisdiction. In the cases where jurisdiction has been recognised to arise in an instantaneous manner, that finding is often qualified by the existence of at least one other potentially determinative factual characteristic. A summary of the case law is illustrative of this approach. ${ }^{318}$

The earliest example of "conditional instantaneous" jurisdiction appeared in Pad. ${ }^{319}$ This application concerned the deaths of seven Iranian men at the hands of Turkish forces. The cause of death was disputed. The applicants alleged that the men had been captured in Iran near the Turkish border and had been taken into Turkey where they were executed ${ }^{320} \mathrm{Although}$ accepting responsibility for the deaths, Turkey asserted that its agents had instead killed the men on Turkish territory by discharging fire from a military helicopter. A Chamber of the ECtHR ruled that Turkey had exercised jurisdiction over the victims but did so without finding it necessary to consider whether the alleged violations had taken place in Turkey or Northern Iran. Instead it sidestepped this critical issue by determining that it was unnecessary to establish the exact location of the helicopter as Turkey had already admitted responsibility. ${ }^{321}$ The result is that although this admissibility decision establishes the possibility of an instantaneous approach to jurisdiction, at best it only sets a very weak precedent and adds little legal certainty to the area.

The issue was again at the forefront of deliberations in two cases shortly following Pad. In the first case, Solomou v. Turkey, ${ }^{322}$ a group of Greek-Cypriot protestors entered the UN-monitored buffer zone between Cyprus and the TRNC. One of the protestors, Solomos Solomou, ran to the Turkish side of the buffer zone and attempted to climb

316 MH17 Crash:Victims' Families Sue Putin and Russia, BBC News, 21 May 2016 (Aug. 2, 2018), available at http://www.bbc.co.uk/news/world-europe-36350520.

317 The irony that this presents the Court with an opportunity to analyse the Banković circumstances in the reverse is not lost on Mark Gibney who comments: "One wonders whether the same result would be reached in the reverse situation, that is, where soldiers on the ground are firing anti-aircraft weapons up into the sky aimed at a civilian aircraft flying overhead." Gibney 2015, at 176. McGoldrick 2004, at 72; Milanović 2011, at 173, 191; Lawson 2011, at 70. Mansur Pad and Others v. Turkey, Application No. 60167/00, Decision (Section III), 28 June 2007. Id. para. 8. Id. para. 54. Solomou and Others v. Turkey, Application No. 36832/97, Judgment (Section IV), 24 June 2008. 
a pole where the Turkish flag was flying. Before he could reach the top of the pole he was shot and killed by Turkish forces. At the time of his death he was located on the territory of the TRNC and so within an area which the Court had previously stated was subject to Turkish spatial jurisdiction in Loizidou. ${ }^{323}$ Despite this, the wording of the Chamber judgment is very different. It stated that "the deceased was under the authority/and or effective control of the respondent State through its agents" (emphasis added), thus implying the exercise of personal rather than spatial jurisdiction. ${ }^{324}$ The Court went on to find that there had been a violation of his right to life. ${ }^{325}$

Again, the Court appears to have found jurisdiction here on an instantaneous basis with the act of shooting giving rise to the jurisdictional link. Nonetheless, it is once again conditional. On this occasion the added condition is that the individual was already within an area under the effective control of Turkey. It would remain very easy for a judge to treat the location of Solomou at the time of his death as entirely determinative. ${ }^{326}$

The second case concerns events that occurred on the same day as Solomou's death. In Andreou, the applicant had attended a vigil being held at the UN buffer zone. ${ }^{327}$ While on the territory of the Southern Republic of Cyprus Andreou was injured by a series of bullets fired indiscriminately from Turkish armed forces and/ or Turkish-Cypriot uniformed personnel on the northern side of the ceasefire line. When considering the question of jurisdiction on this occasion, the Court came closer than ever to establishing an instantaneous notion of jurisdiction. It stated as the "direct and immediate cause" of the injury the applicant sustained was due to actions of the Turkish authorities, she fell within Turkish jurisdiction. ${ }^{328}$

While at first taking this expansive approach, the Court confused the issue by distinguishing the applicant from the victims in Banković. The Court stated that "[u]nlike the applicants in the Banković and Others case she was accordingly within

323 the death of another Greek-Cypriot protester who had forced his way into the UN-monitored buffer zone between Southern Cyprus and the TRNC. There he was beaten to death by a group of Turkish and Turkish-Cypriot civilians and police officers. In assessing jurisdiction in this case the Court was able to establish that Turkish-Cypriot policemen had actively taken part in the beating which led to Isaak's death. It subsequently held that, by virtue of these actions, Isaak had been under the"authority and/or effective control" of Turkey at the time of his death and, as such, fell within its jurisdiction for the purposes of Article 1 - Isaak and Others v. Turkey, Application No. 44587/98, Judgment (Section IV), 24 June 2008. 
territory covered by the Convention."1329 The condition attached to this finding is therefore that instantaneous acts can give rise to jurisdiction on the territory of a Contracting Party to the Convention, but not outside it. Even with this heavy caveat, Rick Lawson has noted that it is difficult to maintain that the Andreou decision is faithful to Banković. ${ }^{30}$ Applying this standard to the Ukrainian crisis would mean that any individual killed by pro-Russian rebels would have fallen within the jurisdiction of the Russian Federation at the time of their injury - but only because Ukraine is a signatory to the Convention. If the approach is broadened to consider other extraterritorial military operations currently being conducted by Russia, Syrian civilians who have been injured or killed in airstrikes by Russian agents in Aleppo would not be deemed to be within Russian jurisdiction. ${ }^{31}$

The final two examples concern the conflict in Iraq. The first, Al-Skeini and Others has been considered in detail above. ${ }^{332}$ Similar to the other cases addressed in this section it can also be perceived to be a conditional instantaneous act case given the circumstances in which some of the victims were killed. Of the six victims in this case, four were not within British custody when they were killed, thus eliminating the applicable de facto control test from interpretation 1. The first victim was killed while walking along a public street, ${ }_{1}^{333}$ the second during a raid on his brother-in-law's home; ${ }^{334}$ the third by a stray bullet which entered her living room ${ }_{i}^{.35}$ the fourth was shot by a British soldier at a checkpoint while driving a minibus home from work. ${ }^{336}$ Despite not being within the custody of, or within a location controlled by, British forces, each of these victims were deemed to be within UK jurisdiction. ${ }^{337}$

The condition which accompanied the instantaneous jurisdiction in this case was that UK forces were exercising public powers in the region at the time, leading the

329

Andreou v. Turkey, supra note 113, para. 25.

Lawson 2011, at 70.

The Court in Al-Skeini closed off the "legal space" argument as a barrier to the application of Convention obligations outside of the territory of Contracting Parties to the Convention. It stated:"the importance of establishing the occupying state's jurisdiction in such cases does not imply, a contrario, that jurisdiction under Art. 1 of the Convention can never exist outside the territory covered by the Council of Europe Member States" - Al-Skeini and Others v. United Kingdom, supra note 18, para. 142; Emma Graham-Harrison, Russian Airstrikes in Syria Killed 2,000 Civilians in Six Months, The Guardian, 15 March 2016 (Aug. 2, 2018), available at https://www.theguardian.com/world/2016/mar/15/russian-airstrikesin-syria-killed-2000-civilians-in-six-months.

See supra Section 1.

Al-Skeini and Others v. United Kingdom, supra note 18, paras. 34-38.

Id. paras. 39-42.

Id. paras. 43-46.

Id. paras. 47-54.

Id. paras. 149 and 150 . 
ECtHR to establish the "personal plus" jurisdiction referred to above. ${ }^{338}$ This condition, and the use of force which gave rise to control, were both necessary to the finding of jurisdiction. If public powers had not been exercised, then the individuals would have fallen outside the United Kingdom's Article 1 jurisdiction. Likewise, it was only the fact that State agents had exercised de facto control over these individuals when they were shot and killed which brought them within the State's jurisdiction at the relevant time. Although the United Kingdom exercised public powers over large swathes of Basrah, their obligations to those individuals only appeared to be triggered by the exercise of control over them.

The second Iraq case is also mentioned above in relation to interpreting jurisdiction through de facto control over locations. Jaloud $v$. Netherlands stood as the clearest opportunity since Banković for the ECtHR to make a direct finding of jurisdiction based on the use of force in an instantaneous manner. As mentioned, the Court found jurisdiction on the basis that the Dutch forces exercised "authority and control over persons passing through the checkpoint."1339 Despite this finding, the applicant's son was only brought within Dutch jurisdiction because he was shot while in transit through the checkpoint. Again, these two conditions, the control over the territory and the shooting of Azhar Jaloud, both appear to be critical to the finding. ${ }^{30}$

The dominant theme running through this body of case law is that although the Court will recognise that jurisdiction can arise instantaneously, it is not yet prepared to do so in an unconditional manner. Although these conditions appear to vary in significance, in almost all of the cases the finding of jurisdiction seems to be dependent on both the exercise of de facto control and at least one external factor. This inconsistency assists neither the State in determining the extent of its legal obligations, nor the families and victims of abuses who seek to hold the persecuting forces accountable.

Raible accurately notes how every new judgment of the ECtHR "seems to either add another layer of confusion or line of case-law different from the rest.".341 In relation to personal jurisdiction more generally, the Court's tendency has been to find the existence of a human rights obligation. Yet the way the Court rationalises the existence of jurisdiction is very inconsistent. This section outlined three diverging interpretations of when a State will exercise de facto control over an individual. The flexibility is broadly favourable towards the alleged victim of a human rights violation, however the uncertainty inherent in such a broad approach creates real practical difficulties for States in their efforts to delineate the extent of their human rights

338 See supra Section 2.

339 Jaloud v. Netherlands, supra note 36, para. 152.

340 Rooney contends that the ECtHR adopted an attribution test to make a finding of jurisdiction in Jaloud. Jane Rooney, The Relationship Between Jurisdiction and Attribution After Jaloud v. Netherlands, 62(3) Netherlands International Law Review 407, 407 (2015).

341 Raible 2016, at 161. 
obligations. When such obligations arise, States have little clarity over the extent of the obligations owed now that the Convention rights can be "divided and tailored."

\subsection{Conclusions as to Eastern Ukraine}

To conclude our analysis of the application of human rights law in Eastern Ukraine, the situation is as unclear as its parallel in Crimea. The ECtHR could determine that Ukraine's obligations will extend throughout its entire territory, subject to the derogations which have been filed. Alternatively, the Court could undertake a detailed factual analysis of the situation in Eastern Ukraine and either limit, or remove, Ukrainian obligations on the basis of the loss of de facto control over territory there. The Court's inconsistency in its previous jurisprudence on this issue makes it difficult to predict which approach it will take.

Russia's ECHR obligations will be dependent on the recognition that the rebels in Donetsk and Luhansk are under the "decisive influence" of the Russian State. If this is established, it may still be unlikely that Russia will be held to have exercised spatial jurisdiction over the areas in question. Instead it is more plausible that Russia will bear responsibility where rebels have exercised personal jurisdiction over individuals, through either taking them into custody, control over locations, or based on instantaneous acts. Although the personal jurisdiction approach is more likely to be established, the lack of clarity over which Convention obligations apply when such jurisdiction is found because of the potential division and tailoring of obligations, leaves another layer of ambiguity relating to what Convention rights apply.

\section{Conclusion}

We have explored the territorial and extra-territorial application of the ECHR in relation to the annexation of Crimea and the conflict in Eastern Ukraine. Scratching beneath the surface of the jurisprudence of the ECtHR has revealed a bewildering degree of complexity and uncertainty as to the potential obligations of each State in these conflicts. This section makes concluding observations about the practical implications of the Court's chronically inconsistent approach to jurisdiction.

The first observation speaks generally to the Court's broad approach in applying the Convention and how this may be followed in relation to Ukraine. This was succinctly summarised by Judge Bonello in the Al-Skeini case. He said

Up until now, the Court has, in matters concerning the extra-territorial jurisdiction of contracting parties, spawned a number of "leading" judgments based on a need-to-decide basis, patchwork case law at best. Inevitably, the doctrines established seem to go too far to some, and not far enough to others. ${ }^{342}$

342 Al-Skeini and Others v. United Kingdom, supra note 18 (Separate Opinion of Judge Bonello), para. 115. Judge Bonello continues:"Principles settled in one judgment may appear more or less justifiable in themselves, but they then betray an awkward fit when measured against principles established in another." 
The Court does not appear to follow any underlying theoretical or principled approach to its findings of jurisdiction. Recognising this, several commentators and judges have attempted to articulate a coherent test for jurisdiction, but the Court is yet to follow any of these suggestions. ${ }^{343}$ With so many different threads, the most prudent way to predict which approach the Court may take in relation to the Ukrainian crisis is to identify the factors to which the ECtHR has accorded most weight. Of these factors, two will be particularly relevant for the Ukrainian crisis.

The first overarching motivation is the Court's desire to avoid a lacuna in the protection offered by the Convention. Whatever conclusion the ECtHR reaches concerning jurisdiction, whether Ukraine still retains jurisdiction or Russia is found to exercise jurisdiction, the ECtHR's primary motivation will be to ensure that the populations of these areas have full access to their Convention rights.

The second relevant overarching motivation which the Court is the avoidance of impunity. This is clearly expressed in the Issa case

Accountability in such situations stems from the fact that Art. 1 of the Convention cannot be interpreted so as to allow a state party to perpetrate violations of the Convention on the territory of another state, which it could not perpetrate on its own territory. ${ }^{344}$

This aspirational approach can explain much of the inconsistency which has developed over the Court's recent jurisprudence. In many respects, although there had been ample jurisprudence which considered the Convention's territorial and extra-territorial application previously, the topic was largely absent from academic

343 Judge Loukis Loucaides proposed a test of "authority" in the Assanidze case. The question he thought should be posed was "whether the person who claims to be within the 'jurisdiction' of a State, High Contracting Party to the Convention, in respect of a particular act can show that the act in question was the result of the exercise of authority by the State concerned." Assanidze v. Georgia, supra note 55 (Separate Opinion of Judge Loucaides). In Al-Skeini Judge Rozakis suggested a structural reorganisation of the Al-Skeini framework. He proposed that there was no real distinction between effective control of an area and state agent authority and control. As a result, he suggested that the effective control of an area exception should form another sub-heading of the state agent authority and control exception. Al-Skeini and Others v. United Kingdom, supra note 18 (Separate Opinion of Judge Rozakis), para. 13. Judge Bonello suggested a test where jurisdiction arose whenever a state has the power to perform, or not to perform, any of the following five functions: "first, by not violating (through their agents) human rights; secondly, by having in place systems which prevent breaches of human rights; thirdly, by investigating complaints of human-rights abuses; fourthly, by scourging those of their agents who infringe human rights; and, finally, by compensating the victims of breaches of human rights." Al-Skeini and Others v. United Kingdom, supra note 18 (Separate Opinion of Judge Bonello), para. 10.

344 Issa and Others v. Turkey, supra note 87, para. 71. The Court in Issa was echoing the Human Rights Committee in Lopez Burgos v. Uruguay where the Committee had stated: "In line with this, it would be unconscionable to so interpret the responsibility under article 2 of the Covenant as to permit a State party to perpetrate violations of the Covenant on the territory of another State, which violations it could not perpetrate on its own territory." Delia Saldias de Lopez v. Uruguay, Communication No. 52/1979, U.N. Doc. CCPR/C/OP/1, at 88 (1984), para. 12.3. 
dialogue until the Banković decision of $2001 .^{345}$ Since 2001, there has been an explosion in jurisprudence and literature concerning the topic. The overarching trend has been towards establishing how States can be held accountable for human rights violations abroad rather than finding obstacles to the Convention's application. As is evident in our section on instantaneous jurisdiction, apart from Banković, the Court has gradually expanded the scope of personal jurisdiction to encompass almost all situations which come before it. In cases emerging from Ukraine it would therefore be unsurprising for the Court to pursue this underlying motivation of preventing States escaping accountability when they commit human rights violations abroad, by extending its interpretation of personal jurisdiction further. Therefore, if Russia is not held to exercise spatial jurisdiction in Eastern Ukraine, the Court may yet find inventive ways to establish the exercise of personal jurisdiction by Russian agents.

This brings us to our second observation which is a practical issue touched upon throughout the analysis. The lack of clarity in the Court's approach means that neither victims and their families, nor Contracting Parties to the Convention, know precisely when jurisdiction will arise, or which rights could apply when it does. Following the ECtHR's jurisprudence and subject to its derogation, Ukrainian responsibilities could extend throughout the entire territory of the State, including Crimea and Eastern Ukraine. Alternatively, Ukraine's responsibilities may be limited to a currently undefined series of positive obligations. It is further possible that Ukraine owes no obligations to individuals within these areas at all. Russian responsibilities are equally unclear. Russia may exercise full spatial jurisdiction throughout Crimea or Eastern Ukraine, or both. With spatial jurisdiction Russia would be obligated to respect all rights within the Convention, including the additional Protocols which it is a party to. Alternatively, Russia may only exercise personal jurisdiction over individuals within Eastern Ukraine. In this scenario, Russia's obligations would be "divided and tailored" to an as yet undefined list of rights which are relevant to the situation.

This chaotic picture presents acute difficulties for those victims of rights abuses in holding the State accountable. Beyond the question of whether they were owed obligations at the relevant time is the question of which rights are applicable. Not only are there significant differences from full obligations, some positive obligations, and only rights applicable to the relevant situation, but as Ukraine and Russia are signatories to different Protocols, the finding of which State exercises jurisdiction on the whole will affect which rights can be applied. For instance, while Ukraine has ratified Protocol 13, which abolishes the death penalty in all circumstances, ${ }^{346}$ Russia is only a signatory to Protocol 6 , which while abolishing the death penalty, still allows

Lush was one of the few commentators to engage with the issue - see Christopher Lush, The Territorial Application of the European Convention on Human Rights: Recent Case Law, 42(4) International \& Comparative Law Quarterly 897 (1993).

346 Council of Europe, Protocol 13 to the European Convention on Human Rights and Fundamental Freedoms on the Abolition of the Death Penalty in All Circumstances, 3 May 2002, E.T.S. 187. 
for executions during times of war. ${ }^{347}$ The Court's inconsistent approach to jurisdiction makes the application of this law unpredictable. ${ }^{348}$

Our final observation is that this unpredictability creates severe policy implications in the Ukrainian context, which may impact upon the Court's relationship with either contracting State. Given that the Court has failed to clearly articulate rules for when the Convention will apply, there will be a degree of scepticism aimed at the Court by either State when it is adjudged to have exercised jurisdiction. For example, if Ukraine is found to be responsible for the full array of Convention rights in Crimea and Eastern Ukraine, minus those which they have adequately derogated from, it would be expected that the Court will have come to this conclusion after conducting a detailed analysis of the situation and noting Ukraine's loss of de facto control. If the Court fails to take such an approach, as it did in relation to Russian control in Isayeva, it will naturally open itself to further justifiable accusations of inconsistency.

A similar complaint could be made by Russia if, for instance, it is held to be in "spatial control" of Eastern Ukraine. The question which could be posed here is why the Court would subject Russia to the test for spatial jurisdiction given that it applied no such test to the British occupation of South-Eastern Iraq. Accusations of selectivity would also arise if, for instance, Russia is held responsible for violations of the right to life concerning the downing of $\mathrm{MH} 17$ through an instantaneous notion of personal jurisdiction where no such jurisdictional link was found for NATO States in Banković.

Given Russia's current strained relationship with the ECtHR, its response to any finding that it had breached Convention obligations in Ukraine would be particularly significant. Whether justified or not, the most likely reaction by Russia would be to accuse the Court of politicisation and selectivity. Speaking after the Ilaşcu decision, President Vladimir Putin warned the Russian people that

our country is coming into collision with a politicisation of judicial decisions. We all know about the case of Ilascu, where the Russian Federation was accused of matters with which it has no connection whatsoever. This is a purely political decision, an undermining of trust in the judicial international system. ${ }^{349}$

Bill Bowring, expert on Russia and the ECtHR, noted before the UK House of Commons Foreign Affairs Committee in May 2007 that "Russia's increasingly tense relationship with Strasbourg raises the question of whether Russia really wants to

347 Protocol 13 to the European Convention on Human Rights and Fundamental Freedoms on the Abolition of the Death Penalty in All Circumstances.

Brooke LJ who grappled with the Article 1 question in the British Court of Appeal hearing of Al-Skeini, noted that it is now time "to set rules which are readily intelligible,"Brooke LJ, R. (Al-Skeini) v. Secretary of State for Defence, supra note 85, para. 110. 
remain a member. ${ }^{1130}$ The strain in the relationship is further evident in the Russian legislation passed in December 2015 allowing for the Russian Constitutional Court to review rulings of international human rights bodies, including the ECtHR, and declare them non-executable if they contravene the Russian Constitution. ${ }^{351}$ None of this is to say that the Court should alter its decisions on the basis of potential political responses from States. Instead, this observation demonstrates how the inconsistency of the Court's decision-making process has the potential to exploit pre-existing tensions and allow for justifiable criticism of the Court. Without a stable approach, the Court risks losing credibility and States may be encouraged to exploit gaps in the weaknesses of the Court's jurisprudence.

The final comment to be made relates to the process the Court follows in finding jurisdiction. Within this exercise it is argued that that de facto control remains the most appropriate characteristic which a Court can use to ascertain whether an area or an individual is within the jurisdiction of a Contracting Party to the ECHR during periods of conflict. Applying this test means that Courts can look beyond complex legal questions and contentious political disputes to evaluate the precise situation on the ground and adjudicate effectively from that basis. Yet if the Court continues to apply this test inconsistently its merits can never truly be realised. The crisis in Ukraine has presented the ECtHR with an opportunity to stamp new authority on its approach to territorially and extra-territorially applying the Convention. It should seize this opportunity to develop a test which is readily intelligible by all parties.

\section{References}

Abresch W. A Human Rights Law of Internal Armed Conflict: The European Court of Human Rights in Chechnya, 16(4) European Journal of International Law 741 (2005).

Allain J. Derogation from the European Convention of Human Rights in the Light of "Other Obligations Under International Law," 5 European Human Rights Law Review 480 (2005).

Balendra N. Defining Armed Conflict, 29(6) Cardozo Law Review 2461 (2008).

Benvenisti E. The Origins of the Concept of Belligerent Occupation, 26(3) Law and History Review 621 (2008).

Besson S. The Extraterritoriality of the European Convention on Human Rights: Why Human Rights Depend on Jurisdiction and What Jurisdiction Amounts To, 25(4) Leiden Journal of International Law 857 (2012).

350 Inquiry into Global Security: Russia, supra note 349, para. 42.

351 Russia Passes Law to Overrule European Human Rights Court, BBC News, 4 December 2015 (Aug. 2, 2018), available at http://www.bbc.co.uk/news/world-europe-35007059; Alexandra Sims, Vladimir Putin Signs Law Allowing Russia to Ignore International Human Rights Rulings, The Independent, 12 December 2015 (Aug. 2, 2018), available at http://www.independent.co.uk/news/world/europe/vladimir-putinsigns-law-allowing-russian-court-to-overthrow-international-human-rights-rulings-a6773581.html. 
Bethlehem D. The Relationship Between International Humanitarian Law and International Human Rights Law in Situations of Armed Conflict, 2(2) Cambridge Journal of International and Comparative Law 180 (2013).

Brownlie I. Principles of Public International Law (Oxford: Oxford University Press, 2008).

Carcano A. The Transformation of Occupied Territory in International Law (Leiden: Brill/Nijhoff, 2015).

Cassese A. The Nicaragua and Tadic Tests Revisited in Light of the ICJ Judgment on Genocide in Bosnia, 18(4) European Journal of International Law 649 (2007).

Copetti Cravo D. Ukraine Liability for Violation of Human Rights in the Downing of Malaysian Airlines Flight MH17, 12 Brazilian Journal of International Law 728 (2015) (in Portuguese).

Corn G. Mixing Apples and Hand Grenades The Logical Limits of Applying Human Rights Norms to Armed Conflict, 1(1) Journal of International Humanitarian Legal Studies 52 (2010).

Costelloe D. Treaty Succession in Annexed Territory, 65(2) International \& Comparative Law Quarterly 343 (2016).

Cowan A. A New Watershed? Re-evaluating Bankovic in Light of Al-Skeini, 1(1) Cambridge International Law Journal 213 (2012).

Crawford J. \& Olleson S. The Nature and Forms of International Responsibility in International Law in International Law 441 (M.D. Evans (ed.), $3^{\text {rd }}$ ed., Oxford: Oxford University Press, 2010).

Crawford J. Draft Articles on Responsibility of States for Internationally Wrongful Acts, with Commentaries, 2 Yearbook of the International Law Commission 1 (2001).

Cullen A. \& Wheatley S. The Human Rights of Individuals in De Facto Regimes Under the European Convention on Human Rights, 13 Human Rights Law Review 691 (2013).

Dennis M.J. Application of Human Rights Treaties Extraterritorially to Detention of Combatants and Security Internees: Fuzzy Thinking All Around, 12(2) ILSA Journal of International \& Comparative Law 459 (2006).

Doswald-Beck L. \& Henckaerts J.-M. Customary International Humanitarian Law (Cambridge: Cambridge University Press, 2005).

Fitzpatrick J. Human Rights in Crisis: The International System for Protecting Human Rights During States of Emergency (Philadelphia: University of Pennsylvania Press, 1994).

Fox G.H. The Occupation of Iraq, 36 Georgetown Journal of International Law 195 (2004-2005).

Giacca G. Economic, Social and Cultural Rights in Armed Conflict (Oxford: Oxford University Press, 2014).

Gibney M. The Downing of MH17: Russian Responsibility?, 15(1) Human Rights Law Review 169 (2015).

Gondek M. Extraterritorial Application of the European Convention on Human Rights: Territorial Focus in the Age of Globalization?, 52 Netherlands International Law Review 349 (2005). 
Goodman R. The Power to Kill or Capture Enemy Combatants, 24(3) European Journal of International Law 819 (2013).

Grant T. Aggression Against Ukraine Territory, Responsibility, and International Law (New York: Palgrave Macmillan, 2015).

Hakimi M. State Bystander Responsibility, 21(2) European Journal of International Law 341 (2010).

Hays Parks W. Part IX of the ICRC Direct Participation in Hostilities Study: No Mandate, No Expertise, and Legally Incorrect, 42 New York University Journal of International Law and Politics 769 (2010).

Kavaldjieva S. Jurisdiction of the European Court of Human Rights: Exorbitance in Reverse?, 37(3) Georgetown Journal of International Law 507 (2006).

Kirchner S. Interim Measures in Inter-State Proceedings Before the European Court of Human Rights: Ukraine v. Russia, 3(1) University of Baltimore Journal of International Law 33 (2015).

Koch J. The Efficacy and Impact of Interim Measures: Ukraine's Inter-State Application Against Russia, 39(1) Boston College International and Comparative Law Review 163 (2016).

Kohen M.G. Secession: International Law Perspectives (Cambridge: Cambridge University Press, 2006).

Krieger H. A Conflict of Norms the Relationship Between Humanitarian Law and Human Rights Law in the ICRC Customary Law Study, 11(2) Journal of Conflict \& Security Law 265 (2006).

Larsen K.M. Territorial Non-Application of the European Convention on Human Rights, 78 Nordic Journal of International Law 73 (2009).

Lawson R. Really Out of Sight? Issues of Jurisdiction and Control in Situations of Armed Conflict under the ECHR in Margins of Conflict: The ECHR and Transitions to and from Armed Conflict 57 (A. Buyse (ed.), Antwerp: Intersentia, 2011).

Leach P. The Chechen Conflict: Analysing the Oversight of the European Court of Human Rights, 6 European Human Rights Law Review 732 (2008).

Loucaides L. Determining the Extra-Territorial Effect of the European Convention: Facts, Jurisprudence and the Bankovic Case, 4 European Human Rights Law Review 391 (2006).

Loucaides L. Is the European Court of Human Rights Still a Principled Court of Human Rights After the Demopoulos Case?, 24(2) Leiden Journal of International Law 435 (2011).

Lubell N. Human Rights Obligations in Military Occupation, 94(885) International Review of the Red Cross 317 (2012).

Lush C. The Territorial Application of the European Convention on Human Rights: Recent Case Law, 42(4) International \& Comparative Law Quarterly 897 (1993).

Malanczuk P. Akehurst's Modern Introduction to International Law ( $7^{\text {th }}$ ed., New York: Routledge, 1997). 
Mastorodimos K. The Utility and Limits of International Human Rights Law and International Humanitarian Law's Parallel Applicability, 5 Review of International Law and Politics 123 (2009).

McGoldrick D. Extraterritorial Application of the International Covenant on Civil and Political Rights in Extraterritorial Application of Human Rights Treaties 41 (F. Coomans \& M.T. Kamminga (eds.), Antwerp: Intersentia, 2004).

Milano E. Unlawful Territorial Situations in International Law - Reconciling Effectiveness, Legality and Legitimacy (Leiden: Brill, 2005).

Milanovic M. \& Papic T. As Bad as It Gets: The European Court of Human Rights's "Behrami and Saramati" Decision and General International Law, 58(2) International \& Comparative Law Quarterly 267 (2009).

Milanovic M. Al-Skeini and Al-Jedda in Strasbourg, 23(1) European Journal of International Law 121 (2012).

Milanovic M. Extraterritorial Application of Human Rights Treaties: Law, Principles, and Policy (Oxford: Oxford University Press, 2011).

Milanovic M. From Compromise to Principle: Clarifying the Concept of State Jurisdiction in Human Rights Treaties, 8 Human Rights Law Review 411 (2008).

Miltner B. Revisiting Extraterritoriality After Al-Skeini: The ECHR and Its Lessons, 33(4) Michigan Journal of International Law 693 (2012).

Modirzadeh N.K. The Dark Sides of Convergence: A Pro-Civilian Critique of the Extraterritorial Application of Human Rights Law in Armed Conflict, 86 International Law Student Series US Naval War Collection 349 (2010).

Moor L. \& Simpson B. Ghosts of Colonialism in the European Convention on Human Rights, 76(1) British Yearbook of International Law 121 (2005).

Norris R. \& Reiton P. The Suspension of Guarantees: A Comparative Analysis of the American Convention on Human Rights and the Constitutions of the States Parties, 30 American University Law Review 189 (1980).

Oppenheim L. et al. Oppenheim's International Law. Vol. 1: Peace. Parts 2-4 (Harlow: Longman, 1992).

Raible L. The Extraterritoriality of the ECHR: Why Jaloud and Pisari Should Be Read as Game Changers, 2 European Human Rights Law Review 161 (2016).

Roth B. The Neglected Virtues of Bright Lines: International Law in the 2014 Ukraine Crises, 21(2) ILSA Journal of International \& Comparative Law 317 (2014-2015).

Ryngaert C. Clarifying the Extraterritorial Application of the European Convention on Human Rights, 28(74) Utrecht Journal of International and European Law 57 (2012).

Sari A. Untangling Extra-Territorial Jurisdiction from International Responsibility in Jaloud v. Netherlands: Old Problem, New Solutions?, 53 Military Law and the Law of War Review 287 (2014).

Schabas W. Synergy or Fragmentation? International Criminal Law and the European Convention on Human Rights, 9(3) Journal of International Criminal Justice 609 (2011).

Scobbie I. Principle of Pragmatics - The Relationship Between Human Rights Law and the Law of Armed Conflict, 14(3) Journal of Conflict and Security Law 449 (2009). 
Shany Y. Taking Universality Seriously: A Functional Approach to Extraterritoriality in International Human Rights Law, 7 Law \& Ethics of Human Rights 47 (2013).

Shaw M. International Law (Cambridge: Cambridge University Press, 2008).

Sheeran S. Reconceptualizing States of Emergency Under International Human Rights Law: Theory, Legal Doctrine, and Politics, 34(3) Michigan Journal of International Law 491 (2013).

Szydło M. Extra-Territorial Application of the European Convention on Human Rights After Al-Skeini and Al-Jedda, 12(1) International Criminal Law Review 271 (2012).

Talmon S. The Responsibility of Outside Powers for Acts of Secessionist Entities, 58(3) International \& Comparative Law Quarterly 493 (2009).

Trilsch M. \& Ruth A. Bankovic v. Belgium, 97 American Journal of International Law 168 (2003).

Van der Sloot B. Is All Fair in Love and War? An Analysis of the Case Law on Article 15 ECHR, 53(2) Military Law and Law of War Review 319 (2014).

Van der Wilt H. \& LyngdorfS. Procedural Obligations Under the European Convention on Human Rights: Useful Guidelines for the Assessment of "Unwillingness" and "Inability" in the Context of the Complementarity Principle, 9 International Criminal Law Review 39 (2009).

Watkin K. Controlling the Use of Force: A Role for Human Rights Norms in Contemporary Armed Conflict, 98(1) American Journal of International Law 1 (2004).

White R.C.A. Tackling Political Disputes Through Individual Applications, 1 European Human Rights Law Review 61 (1998).

Wilde R. Legal "Black Hole"? Extraterritorial State Action and International Treaty Law on Civil and Political Rights, 26(3) Michigan Journal of International Law 739 (2005).

Wilde R. The Extraterritorial Application of International Human Rights Law on Civil and Political Rights in Routledge Handbook of International Human Rights Law 635 (S. Sheeran \& N. Rodley (eds.), Abingdon, UK: Routledge, 2013).

Williams J. Al Skeini: A Flawed Interpretation of Banković, 23(4) Wisconsin International Law Journal 687 (2005).

\section{Information about the authors}

Stuart Wallace (Cambridge, United Kingdom) - Lecturer and Director of Studies in Law, Homerton College, University of Cambridge (K203 Cavendish Building, Homerton College, Hills Road, Cambridge, CB2 8PH, United Kingdom; e-mail:sw791@cam.ac.uk).

Conall Mallory (Newcastle upon Tyne, United Kingdom) - Lecturer in Law, Newcastle University (Newcastle Law School, 21-24 Windsor Terrace, Newcastle University, NE1 7RU, United Kingdom; e-mail: Conall.Mallory@newcastle.ac.uk). 